Patryk Kukliński*

ORCID: 0000-0003-2286-0143

Uniwersytet Warszawski

https://doi.org/10.19195/1733-5779.37.9

\title{
Praktyka funkcjonowania Krajowego Ośrodka Zapobiegania Zachowaniom Dyssocjalnym. Uwagi na tle wyroku Trybunału Konstytucyjnego z 23 listopada 2016 roku w sprawie K 6/14 - część II
}

JEL Cassification: K10, K38

Słowa kluczowe: izolacja postpenalna, sprawcy niebezpieczni, pozbawienie wolności, Krajowy Ośrodek Zapobiegania Zachowaniom Dyssocjalnym, wyrok Trybunału Konstytucyjnego z 23 listopada 2016 roku w sprawie K 6/14

Keywords: post-penal detention, dangerous perpetrators, deprivation of liberty, National Centre for the Prevention of Antisocial Behaviour, the judgment of the Polish Constitutional Court from 23 November 2016, case no. K 6/14

Abstrakt: Prezentowany tekst to kontynuacja rozważań autora poczynionych w artykule, który ukazał się w 35 tomie czasopisma. Analizuje on wyselekcjonowane bieżące problemy związane $\mathrm{z}$ funkcjonowaniem Krajowego Ośrodka Zapobiegania Zachowaniom Dyssocjalnym w Gostyninie, który powstał w 2014 roku. Punktem odniesienia dla rozważań autora stał się wyrok Trybunału Konstytucyjnego w sprawie K 6/14. Z perspektywy ponad siedmiu lat stosowania ustawy z 22 listopada 2013 r. oraz w odniesieniu do argumentacji Trybunału, autor rozpatruje kwestie związane z wymogiem dystansu izolacji postpenalnej od kary kryminalnej, a także z pozycją i rolą sędziów oraz biegłych w procesie stosowania tej ustawy. Odwołuje się również do strajku głodowego pacjentów tego ośrodka, który stał się wyrazem niezgody na liczne nierozwiązane problemy. Oba artykuły prowadzą do dwóch podstawowych wniosków. Po pierwsze, dowodzą, że wdrożona regulacja jest wyjątkowo nieefektywna. Po drugie, wskazują, że pozostaje ona sprzeczna ze standardami ochrony wolności i praw człowieka.

* Opiekun naukowy (Scientific Tutor) — prof. dr hab. Marek Zubik 


\title{
The functioning practice of the National Centre for the Prevention of Antisocial Behaviour. Comments on the Constitutional Court judgment dated on 23 November 2016 in case no. K 6/14 - part II
}

\begin{abstract}
The following text continues the considerations made in the author's article, which appeared in volume 35 of the journal. This text analyses selected current problems connected to the functioning of the National Centre for the Prevention of Antisocial Behaviour in Gostynin, which was established in 2014. The point of reference for author's deliberations is the judgment of the Polish Constitutional Court (case no. K 6/14). The author, from the perspective of over seven years of the law's application and in relation to the arguments of the court, analyses problems related to distance requirement of post-penal detention from criminal penalty, as well as the position and role of judges and experts in the process of law application. He also refers to the hunger strike of the National Centre patients, which became an expression of opposition to numerous unresolved problems. Both articles lead to two basic conclusions. Firstly, they prove that the introduced regulation is extremely ineffective. Secondly, they indicate that it is contrary to the standards of human freedoms and rights protection.
\end{abstract}

\section{Wprowadzenie}

Zgodnie $\mathrm{z}$ ustaleniami poczynionymi w poprzednim artykule należy przypomnieć, że ustawa o postępowaniu wobec osób z zaburzeniami psychicznymi stwarzających zagrożenie życia, zdrowia lub wolności seksualnej innych osób (dalej: ustawa, ustawa z 2013 roku) ${ }^{1}$ w ocenie jej twórców miała stanowić konkretne narzędzie służące ochronie społeczeństwa i pozwalające na terapię, a następnie przywrócenie do społeczeństwa rzeczonych „osób stwarzających zagrożenie”. Ustawa wprowadziła dwa nowe środki, wykonywane po odbyciu przez skazanego pełnego wymiaru kary — umieszczenie w Krajowym Ośrodku Zapobiegania Zachowania Dyssocjalnym w Gostyninie (dalej: Ośrodek, KOZZD) albo zastosowanie nadzoru prewencyjnego. KOZZD to placówka lecznicza, podlegająca ministrowi właściwemu do spraw zdrowia (art. 5 ust. 1 i 2 ustawy), w której prowadzi się postępowanie terapeutyczne (art. 4 ust. 3 ustawy). Co do zasady izolacja ma w tym przypadku charakter bezterminowy (art. 14 ust. 4 ustawy). W toku procedowania nad ustawą, a następnie w procesie jej stosowania, prawnicy, psychiatrzy i psychologowie zgłaszali liczne problemy związane z proponowanymi rozwiązaniami, a zwłaszcza detencją w Ośrodku, która stanowi głęboką ingerencję w wolności i prawa tam umieszczonych. KOZZD działa od ponad siedmiu lat - w tym czasie sądy uznały, że tylko cztery osoby (stan na 31 sierpnia 2021 roku) ${ }^{2}$ osiągnęły wyniki terapeutyczne, które uzasadniają zwolnienie ich z Ośrodka (tryb przewidziany przez art. 47 ust. 1 ustawy). Placówka boryka się z licznymi trudnościami, między

${ }^{1}$ Ustawa z dnia 22 listopada 2013 roku o postępowaniu wobec osób z zaburzeniami psychicznymi stwarzających zagrożenie życia, zdrowia lub wolności seksualnej innych osób, Dz.U. z 2021 r. poz. 1638 .

${ }^{2}$ Według informacji przekazanych w rozmowie telefonicznej przez dr Ewę Dawidziuk dyrektorkę Zespołu do spraw Wykonywania Kar w Biurze Rzecznika Praw Obywatelskich. 
innymi wadliwą i nieskuteczną metodyką terapeutyczną oraz coraz większym przeludnieniem ${ }^{3}$ obiektu, które wpływa na znaczące pogorszenie panujących tam warunków bytowych. Geneza tego problemu wiąże się w szczególności z nieprecyzyjnie i zbyt szeroko sformułowanym zakresem podmiotowym ustawy. Aspekty te, na tle wyroku Trybunału Konstytucyjnego (dalej: TK, Trybunał) z 23 listopada 2016 roku w sprawie K 6/14, zostały omówione w artykule autora z wcześniejszego wydania czasopisma. Stanowi on pierwszą część szerszych rozważań na temat izolacji postpenalnej w Polsce. Ich kontynuacja znajduje się w poniższym tekście.

\section{Uwagi na tle wyroku Trybunału Konstytucyjnego w sprawie K 6/14 — ciąg dalszy}

Trybunał w wyroku w sprawie K 6/14 uznał ustawę z 2013 roku za zasadniczo zgodną z Konstytucją RP. Z perspektywy czasu warto jednak przyjrzeć się zwłaszcza tym kwestiom, które pozostają wysoce problematyczne w praktyce funkcjonowania tej ustawy w porządku prawnym. Ich identyfikacja prowadzi do wniosku, że nowelizacja jest konieczna nie tylko na poziomie materii ustawowej, ale także aktów wykonawczych. W drugiej części rozważań zostanie omówiony problem naruszenia wymogu dystansu izolacji postpenalnej od kary kryminalnej. W polskich warunkach wynika on w szczególności z niewystarczającego dostępu do aktywności fizycznej, zajęć sportowych i kulturalnych, braku możliwości podejmowania kształcenia i pracy oraz niemożności łagodzenia reżimu izolacji w przypadku wieloletnich pobytów, na przykład przez system przepustek. Zauważają to nie tylko pełnomocnicy izolowanych i pracownicy Biura Rzecznika Praw Obywatelskich i innych instytucji monitorujących KOZZD, lecz także jego pacjenci, którzy pod koniec czerwca 2020 roku zdecydowali się na rozpoczęcie protestu głodowego ${ }^{4}$. Poza tym analiza zostanie zorientowana na wątpliwości dotyczące trudnej sytuacji, w której znaleźli się sędziowie i biegli zmuszeni do stosowania ustawy.

\section{Naruszenie wymogu dystansu}

Lektura wyroku Trybunału Konstytucyjnego w sprawie K 6/14 wymaga też rozważenia, czy z kilkuletniej praktyki stosowania ustawy z 2013 roku nie wynika, że w polskich warunkach narusza się tak zwany wymóg dystansu. Polega on na wyraźnym rozróżnieniu modelu wykonywania kary pozbawienia wolności

3 Aktualnie w Ośrodku przebywa aż 90 osób, poza tym dwie przeniesiono do oddziału zamiejscowego, to jest Regionalnego Ośrodka Psychiatrii Sądowej w Starogardzie Gdańskim (stan na 31 sierpnia 2021 roku).

${ }^{4}$ Kolejny miał miejsce w dniach 1-9 lutego 2021 roku. Zob. KOZZD Gostynin. Jak Minister Zdrowia reaguje na sytuację w Ośrodku, https://www.rpo.gov.pl/pl/content/kozzd-gostynin-protest-glodowt-rpo-do-ministra-zdrowia (dostęp: 3.03.2021). 
od stosowania środka zabezpieczającego w postaci prewencyjnej detencji, która ma miejsce już po odbyciu kary. Wymóg ten został sformułowany w orzecznictwie Federalnego Trybunału Konstytucyjnego (dalej: FTK). FTK podkreślił konieczność takiego zróżnicowania już w wyroku z 5 lutego 2004 roku $^{5}$. Poza uwydatnieniem zabezpieczającego, specjalnego charakteru takiej detencji (dla izolowanego i dla członków społeczeństwa) oraz konieczności zachowania proporcjonalności w jej stosowaniu, niemiecki sąd konstytucyjny słusznie zwrócił uwagę na problem jednostek, które w ramach takiego środka będą odseparowanie od społeczeństwa przez długie lata, a nawet całe życie. To właśnie tej kategorii osób niebezpiecznych powinien zostać zapewniony pewien substytut życia na wolności przez wprowadzenie konkretnych udogodnień. Co więcej, w ocenie FTK celem izolacji jednostek, które mają szansę na readaptację społeczną, musi być przygotowanie do przyszłego życia w warunkach wolnościowych, a nie wyłącznie proste odseparowanie od społeczeństwa osób uznanych za niebezpieczne. Zapewnienie wspomnianych udogodnień ${ }^{6}$ pozostaje w sferze obowiązków pozytywnych państwa. Braki ustawodawcze, zwłaszcza w zakresie szczegółowego określenia praw i obowiązków izolowanych, przekładają się na niemożność osiągnięcia podstawowych (i jednocześnie najistotniejszych) celów związanych z detencją postpenalną — prowadzenia skutecznej terapii, której efektem będzie powrót do życia na wolności i postępowanie zgodne z zasadami współżycia społecznego. Tego typu luki prawne mogą prowadzić do zbyt daleko posuniętej i niekorzystnej arbitralności ze strony nie tylko władz ośrodków detencji, lecz także ich personelu. Pozostawienie tak istotnych kwestii poza przedmiotem regulacji i brak precyzyjnych kryteriów podejmowania decyzji związanych z uznaniem osoby za niebezpieczną, a co za tym idzie — kształtowaniem jej sytuacji prawnej i osobistej, tylko intensyfikuje to ryzyko ${ }^{7}$.

W wyroku FTK z 4 maja 2011 roku $^{8}$ zostało wręcz wyliczonych siedem konstytucyjnych warunków, których spełnienie pozwala na detencję postpenalną ${ }^{9} \mathrm{Na}$ szczególną uwagę zasługują zwłaszcza dwa kryteria. Pozostają one związane ze

5 Wyrok Drugiego Senatu Federalnego Trybunału Konstytucyjnego z dnia 5 lutego 2004 roku, 2 BvR 2029/01; BVerfGE 109, 133; pkt C.III.1.aa.

${ }^{6}$ Wśród nich wymienić można zagwarantowanie możliwości rozwoju własnych zainteresowań, podejmowania pracy, ale i co do zasady nieograniczonego dostępu do powierzchni i urządzeń w ramach miejsca detencji, a nawet kontrolowanych wyjść poza nie.

7 M. Płatek, Niebezpieczni w prawie karnym - Legal fiction czy fiction of legality?, [w:] Księga pamiątkowa prof. Lecha Gardockiego. Między nauką a praktyką prawa karnego, red. S. Żółtek, Warszawa 2014, s. 289.

8 Wyrok Drugiego Senatu Federalnego Trybunału Konstytucyjnego z dnia 4 maja 2011 roku, 2 BvR 2365/09, 2 BvR 740/10, 2 BvR 2333/08, 2 BvR 1152/10, 2 BvR 571/10; BVerfGE 128, 326; pkt C.I.ee.1-7.

9 Wyrok ten zapadł już na tle wyroku Europejskiego Trybunału Praw Człowieka z dnia 17 grudnia 2009 roku w sprawie M. przeciwko Niemcom, skarga nr 19359/04. Wynika z niego między innymi, że izolacja postpenalna musi czynić zadość gwarancjom przewidzianym w art. 7 ust. 1 i art. 5 
sposobem uregulowania codziennego funkcjonowania placówek izolacyjnych. Po pierwsze, umieszczonemu należy zapewnić rzeczywistą perspektywę powrotu do społeczeństwa, w tym przez zachęcanie do podjęcia pracy. Po drugie, wymagana jest możliwość łagodzenia warunków izolacji zgodnie z potrzebą przygotowania jednostki niebezpiecznej do życia na wolności ${ }^{10}$. Są to ważne, choć niejedyne, sposoby budowania motywacji do podążania ścieżką proponowaną przez terapię. Takimi filarami są również dostęp do nauki i rozwoju zawodowego, które nie tylko motywują, lecz także przystosowują do życia w rzeczywistości poza miejscem izolacji. FTK stwierdził ponadto, że im dłużej trwa izolacja niebezpiecznego, tym intensywniejsza powinna być jej sądowa kontrola. Przytoczenie w tym miejscu argumentacji FTK nie jest przypadkowe. Pozwala ono nie tylko na zestawienie elementów niemieckiego standardu z polską praktyką, ale również na wykazanie, że mimo iż w trakcie procedowania nad ustawą z 2013 roku czerpano z wzorców niemieckich, to ich recepcja pozostała wadliwa i niepełna. Polski sąd konstytucyjny w wyroku w sprawie K 6/14 nie dopatrzył się naruszenia wymogu dystansu przez ustawowe rozwiązania, uznając, że przeszły one ,test dostatecznej różnicy"11. Dokładniejsza analiza praktyki funkcjonowania KOZZD od 2014 roku uprawnia jednak do stwierdzenia, że w Polsce dochodzi do naruszenia pewnych składowych tego wymogu.

Polski prawodawca nie uregulował wielu kwestii związanych z codziennym życiem pacjentów w Ośrodku. Możliwość podejmowania aktywności fizycznych w KOZZD pozostaje wysoce ograniczona. Jeszcze w 2020 roku z regulaminów wynikało, że każdy nowoprzyjęty pacjent może odbyć pierwszy spacer dopiero po tygodniowym pobycie w Ośrodku (\$ 6 pkt 2$)^{12}$. Po upływie tego terminu umieszczonym przysługiwała tylko godzina spaceru dziennie (w weekendy półtorej godziny) ${ }^{13}$. Niewielkie zmiany w tym zakresie nastąpiły w efekcie prote-

EKPC, a niedopuszczalne jest zwłaszcza retroaktywne stosowanie przepisów dotyczących detencji takich sprawców.

10 Opinie stanowiące podstawę stosowania środka zabezpieczającego w postaci detencji po odbyciu kary powinny być wydawane na przykład przez niezależne grupy składające się z biegłych doświadczonych w obszarze wykonywania kar i środków karnych.

11 W. Zalewski, Detencja „terapeutyczna” - watpliwości konstytucyjne i politycznokryminalne w kontekście ustawy o ,,bestiach”, „Gdańskie Studia Prawnicze” 2018, nr 40, s. 386.

12 Takie ograniczenie zostało przewidziane w przypadku pacjentów wszystkich czterech oddziałów KOZZD. Warto zauważyć, że regulaminy poszczególnych oddziałów różnicują stan wolności i praw umieszczonych. Zob. regulaminy Ośrodka w Biuletynie Informacji Publicznej Krajowego Ośrodka Zapobiegania Zachowaniom Dyssocjalnym w Gostyninie, http://kozzd-gostynin.bip.eur.pl/public/?id=179972 (dostęp: 19.07.2020). Co ciekawe, najnowszy regulamin w wersji z dnia 28 czerwca 2021 roku zniósł zróżnicowanie poszczególnych oddziałów, a także ograniczenie dotyczące spacerów.

13 Przestrzenią przeznaczoną do spacerów jest droga przeciwpożarowa przy budynku. Wcześniej służył ku temu teren zielony z dużym klombem, jednak jak wynika z relacji pacjentów, z powodu związanych z zakłócaniem ciszy skarg personelu, mającego swoje gabinety właśnie po 
stu pacjentów podjętego 23 czerwca 2020 roku. Europejski Komitet do spraw Zapobiegania Torturom oraz Nieludzkiemu lub Poniżającemu Traktowaniu albo Karaniu już po wizytacji w 2017 roku rekomendował, by „wszyscy pacjenci mogli korzystać z nieograniczonego dostępu do ćwiczeń na zewnątrz w ciągu dnia, chyba że aktywności związane z leczeniem wymagają, że muszą przebywać na oddziale" 14 . W obiekcie znajduje się sala do sportu i rekreacji wyposażona w bieżnie, rowery stacjonarne i stół do tenisa stołowego. Pozostaje ona do dyspozycji godzinę dziennie ${ }^{15}$, co może stanowić jeden z powodów małego zainteresowania ze strony umieszczonych. Tymczasem rola aktywności fizycznej w codziennym funkcjonowaniu i procesie terapeutycznym jest niebagatelna. Zajęcia sportowe „rozładowują napięcie, wzmacniają mechanizmy kontroli wewnętrznej, przyczyniają się do rozwoju antycypacji konsekwencji swoich czynów"16. Efektem wprowadzenia tego typu aktywności mogą być pozytywne zmiany w osobowości pacjentów — wielokrotnie wskazują na nie autorzy analizujący zagadnienie resocjalizacji przez sport $\mathrm{w}$ warunkach więziennych ${ }^{17}$. Z tej perspektywy sport

tej stronie placu, miejsce aktywności fizycznej przeniesiono na drogę przeciwpożarową. Do dyspozycji umieszczonych w Ośrodku pozostają ławki. W sezonie letnim na placu pojawiają się boisko do siatkówki oraz parasole chroniące przed słońcem. Teren spacerowy jest dostępny dla wszystkich pacjentów, także jedynej kobiety przebywającej w KOZZD. Wnioskowała ona o możliwość odbywania spacerów na terenie przy klombie, jednak w ocenie kierownika placówki jest to niemożliwe ze względów organizacyjnych. W opinii przedstawicieli Krajowego Mechanizmu Prewencji Tortur (dalej: KMPT) to niejako „przyzwolenie na molestowanie seksualne”, a sytuacja może prowadzić nawet do naruszenia art. 3 EKPC. Więcej Raport przedstawicieli Krajowego Mechanizmu Prewencji Tortur z wizytacji Krajowego Ośrodka Zapobiegania Zachowaniom Dyssocjalnym w Gostyninie przeprowadzonej w dniach 18-20 lutego 2019 roku (wyciąg), KMP.574.1.2019.JZ, https://www.rpo.gov.pl/pl/content/kmp/od-1550480400-do-1550653200-wizytacja-w-krajowym-o\%C5\%9Brodku-zapobiegania-zachowaniom-dyssocjalnym-w-gostyninie, s. 11-13 (dostęp: 17.02.2020). O trudnej sytuacji jedynej pacjentki w KOZZD informowało między innymi Biuro Rzecznika Praw Obywatelskich i wybrane media. Zob. M. Baczyński, J. Schwertner, Dobra i zła Janinka. Dlaczego państwo zawiodto obie?, https://wiadomosci.onet.pl/tylko-w-onecie/dobra-i-zla-janinka-dlaczego-panstwo-zawiodlo-obie/hl7nc5c (dostęp: 16.03.2020).

14 Raport dla rządu Rzeczpospolitej Polskiej z wizyty Europejskiego Komitetu do spraw Zapobiegania Torturom oraz Nieludzkiemu lub Poniżającemu Traktowaniu albo Karaniu przeprowadzonej w Polsce w dniach 11-22 maja 2017 roku, CPT (2017) 62, https:/www.rpo.gov.pl/pl/content/ raport-dla-polski-o-metodach-zapobiegania-torturom-po-polsku-resort-sprawiedliwo $\% \mathrm{C} 5 \% 9 \mathrm{Bci}$ -opublikowa\%C5\%82, s. 63-64 (dostęp: 18.02.2020).

15 Raport KMPT, op. cit., s. 13.

16 R. Poklek, Wplyw aktywności fizycznej na poziom agresji młodocianych przestępców, „Zeszyty Naukowe Wyższej Szkoły Pedagogiki i Administracji w Poznaniu” 2006, nr 2, s. 235.

17 A. Kosendiak, D. Trzeciak, Motywy i czynniki warunkujące poziom aktywności fizycznej aresztowanych oraz skazanych w warunkach izolacji, ,Rozprawy Naukowe Akademii Wychowania Fizycznego we Wrocławiu” 2019, nr 64, s. 71; M. Konopczyński, Metody twórczej resocjalizacji. Teoria i praktyka wychowawcza, Warszawa 2010, s. 244; A. Brzezińska-Rybacka, Zarys wspótczesnej koncepcji resocjalizacji - metodyka i ogólne zasady, „Roczniki Pedagogiczne” 11 (47), 2019, nr specjalny, s. 123. 
to narzędzie służące do budowania poczucia własnej wartości, zmiany w postrzeganiu osobistych możliwości, a także kształtowania umiejętności rozwiązywania problemów bez wchodzenia w konflikt z prawem ${ }^{18}$. W związku z tym tylko wyjątkowe sytuacje powinny ograniczać dostęp do pacjentów KOZZD do aktywności fizycznej, zarówno w obiekcie, jak i poza nim. Nie powinien być on limitowany do jednej godziny dziennie.

Pacjentom Ośrodka nie stwarza się także możliwości do wykonywania pracy. Nie otrzymują oni szansy na uzyskanie lub doskonalenie kwalifikacji zawodowych albo przekwalifikowanie. Nie mogą zdobywać nowych zainteresowań, a w realizacji dotychczasowych napotykają na liczne problemy ${ }^{19}$. W analogicznej placówce w niemieckim Rosdorfie w Dolnej Saksonii osoba izolowana może podejmować pracę, uczestniczyć w kształceniu, doskonaleniu zawodowym czy też w terapii przez pracę (art. 37). I choć nie jest to obowiązek detencjonowanego, organ penitencjarny ${ }^{20}$ na wniosek izolowanego, któremu dotychczas nie zaoferowano takich aktywności lub który odmówił ich wykonania, powinien ,zaproponować mu czynność odpowiadającą [jego] zdolnościom, sprawnościom i zainteresowaniom" (art. 38). Praca i inne formy samorozwoju w Niemczech mogą odbywać się nawet poza ośrodkiem detencji (art. 39), a izolowanemu przysługuje wynagrodzenie za pracę (art. 42). Z ustawy wynika też wprost obowiązek wypełnienia czasu wolnego, nie jest to zatem kwestia pozostawiona swobodnemu uznaniu kierownictwa placówki. Co więcej, oferty dotyczące spędzania czasu wolnego (propozycje kulturalne, sportowe, ale i w zakresie doskonalenia) muszą uwzględniać życzenia i potrzeby

18 A. Jaworska, Aktywność fizyczna w zakładach karnych a podstawowe wymiary osobowości mężczyzn odbywających karę pozbawienia wolności, „,Resocjalizacja Polska” 2015, nr 9, s. 138-140.

19 Pacjent Ośrodka, który z zawodu jest stolarzem, w trakcie wykonywania kary 25 lat pozbawienia wolności mógł się rozwijać. W rozmowie z przedstawicielami RPO stwierdził: „okna porobiłem na całym bloku, a sobie w celi taką boazerię, że aż przyszła telewizja, żeby pokazać”. „Praca pomagała mi nie zwariować". Tymczasem w KOZZD możliwość jego pracy stolarskiej została wyraźnie ograniczona. Pan J. do stolarki otrzymał tylko plastikowy nóż i papier ścierny. Inny umieszczony w KOZZD w trakcie odbywania kary w więziennym oddziale terapeutycznym pisał wiersze, używając do tego komputera. Uczestniczył w konkursach, w których otrzymywał nagrody za swoją twórczość. W Ośrodku nie uzyskał zgody na posiadanie komputera, bo w ocenie kierownika KOZZD do realizacji w tym zakresie nie jest mu niezbędny - wystarczą kartki papieru. Takie pozwolenie otrzymał najprawdopodobniej dopiero w wyniku protestu, który miał miejsce w ostatnim tygodniu czerwca 2020 roku. Zaistniałe sytuacje nie mogą pozostać bez wpływu na ogólną kondycję czy samopoczucie pacjentów, ale i poziom motywacji do terapii. Ilustrują one wyłącznie izolacyjny (a nie terapeutyczny i readaptacyjny) charakter detencji w Ośrodku oraz świadczą o konieczności funkcjonowania pacjentów w warunkach trudniejszych niż więzienne. Więcej M.K. Nowak, Ośrodek w Gostyninie gorszy niż więzienie. Taki sam w Niemczech leczy i pomaga wrócić do normalnego życia, https://oko.press/niemiecki-osrodek-dla-niebezpiecznych/ (dostęp: 17.02.2020); E. Dawidziuk, Izolacja od społeczeństwa po odbyciu w pelni kary pozbawienia wolności, „Archiwum Kryminologii” 41, 2019, nr 1, s. 239.

${ }^{20} \mathrm{~W}$ niemieckich landach terapia odbywa się w ramach placówek funkcjonujących przy zakładach karnych. 
osób izolowanych. Niemiecki ośrodek ma obowiązek stymulowania i wspierania gotowości osoby stwarzającej zagrożenie społeczne do aktywnego uczestnictwa w proponowanych formach spędzania czasu wolnego (art. 66). W niemieckich warunkach możliwe jest nawet zarządzenie środków ograniczających izolację. Mogą one przybrać formę wyjścia na określony czas w ciągu dnia (z towarzyszeniem lub bez), wyjścia krótkoterminowego (maksymalnie do dwóch tygodni), a nawet długoterminowego (na okres do sześciu miesięcy), przygotowującego do potencjalnego zwolnienia (art. 16). Przepis ten przewiduje także wyjścia związane z wykonywaniem pracy, zarówno pod nadzorem funkcjonariusza służby penitencjarnej, jak i bez niego. Ustawa wprowadza również kategorię środków ograniczających izolację „,z ważnego powodu”, do których zaliczana jest między innymi „choroba stanowiąca zagrożenie życia”, „śmierć członka rodziny” oraz „uczestnictwo w wyznaczonym terminie w sprawie sądowej, na którą osoba izolowana została wezwana" (art. 17) ${ }^{21}$. W Polsce kwestie pracy, kształcenia i doskonalenia, a także czasu wolnego w KOZZD pozostały w całości poza obszarem ustawowej regulacji.

Umieszczeni w Ośrodku nie mają żadnej możliwości jego czasowego opuszczenia. Ustawa z 2013 roku nie przewiduje tego nawet w sytuacjach nadzwyczajnych, jak poważna choroba czy śmierć członka rodziny ${ }^{22}$. To kolejny przykład niekorzystnego różnicowania sytuacji prawnej pacjentów KOZZD w odniesieniu do reżimu więziennego. Jeszcze w trakcie wykonywania kary pozbawienia wolności mieli oni co do zasady możliwość uzyskania przepustek (tak zwanych losowych, systemowych lub w formie nagród) na zasadach przewidzianych przez kodeks karny wykonawczy ${ }^{23}$ (dalej: k.k.w.), choć zależało to między innymi od typu zakładu karnego, w którym odbywali kary. We wszystkich rodzajach zakładów skazanym może zostać udzielona zwłaszcza tak zwana przepustka losowa, służąca spotkaniu z poważnie chorym członkiem rodziny, pozwalająca na uczestnictwo $\mathrm{w}$ pogrzebie członka rodziny oraz w innych wypadkach szczególnie ważnych dla skazanego (art. 141a $\S 1$ k.k.w.). Decydentem w tym przypadku jest dyrektor zakładu karnego, a przepustka może zostać zrealizowana pod konwojem funkcjonariusza Służby Więziennej, osoby godnej zaufania lub samodzielnie przez czas nieprzekraczający pięciu dni ${ }^{24}$. Po odbyciu kary pozbawienia wolności i umiesz-

21 Ustawa kraju związkowego Dolna Saksonia z dnia 12 grudnia 2012 roku o pobycie w izolacji osób stanowiących zagrożenie dla społeczeństwa, Nds. SVVollzG, https://www.rpo.gov.pl/sites/ default/files/Ustawa\%20kraju\%20zwi\%C4\%85zkowego\%20Dolna\%20Saksonia\%20o\%20pobycie $\% 20$ w $\% 20$ izolacji $\% 20$ os $\%$ C3\%B3b\%20stanowi $\%$ C4\%85cych\%20zagro\%C5\%BCenie $\% 20$ dla\%20spo\%C5\%82ecze \%C5\%84stwa.pdf (dostęp: 21.03.2020).

22 Pacjenci opuszczają Ośrodek pod konwojem pracowników ochrony głównie w celu uzyskania zewnętrznej pomocy medycznej czy uczestnictwa w rozprawach sądowych.

23 Ustawa z dnia 6 czerwca 1997 roku — Kodeks karny wykonawczy, Dz.U. z 2021 r. poz. 53 ze zm.

24 A. Świergała, Łączność skazanych ze światem zewnętrznym - kontakty poza murami zakładu karnego, „Studenckie Zeszyty Naukowe” 2019, nr 41, s. 157-163. 
czeniu w KOZZD izolowani stracili jakąkolwiek szansę na taką formę kontaktu ze światem zewnętrznym. Przepustki to istotny element reintegracji społecznej, szczególnie na poziomie utrzymania dobrych relacji z rodziną lub powrotu do nich. Readaptacja w ramach tej grupy „umożliwia dalsze, dobre społeczne funkcjonowanie zwolnionego" 25 , będąc niejako pierwszym krokiem do prawidłowego współżycia również w ramach innych grup społecznych. W warunkach umieszczenia w Ośrodku opcje uzyskania przepustek zostały zupełnie pominięte. Pacjenci nie mają więc możliwości uczestnictwa w wielu ważnych wydarzeniach rodzinnych. W poszczególnych przypadkach może to oznaczać zupełne (wieloletnie, a nawet stałe) odcięcie izolowanych od najbliższych w kontaktach bezpośrednich, w szczególności gdy członkowie rodziny z różnych powodów nie mogą uczestniczyć w odwiedzinach w KOZZD. Taka sytuacja może generować naruszenie prawa do poszanowania życia prywatnego i rodzinnego ${ }^{26}$ zagwarantowanego przez art. 8 EKPC ${ }^{27}$. Przepustki pozwalają także na zdobywanie wiedzy i kwalifikacji ${ }^{28}$ poza Ośrodkiem, istotnych z perspektywy konieczności powrotu na rynek pracy. Tymczasem w polskich warunkach pacjenci mają ograniczone

${ }^{25} \mathrm{H}$. Machel, Rodzina skazanego jako współuczestnikjego resocjalizacji penitencjarnej, readaptacji i reintegracji społecznej, „Resocjalizacja Polska” 2014, nr 7, s. 46.

${ }^{26}$ Europejski Trybunał Praw Człowieka (dalej: ETPC) stoi na stanowisku, że z art. 8 EKPC nie wynika gwarancja bezwarunkowego prawa do opuszczenia zakładu karnego lub aresztu tymczasowego w celu uczestnictwa w pogrzebie krewnego. To organy krajowe są uprawnione do oceny wpływających w tej kwestii wniosków. W sprawach Płoski przeciwko Polsce czy Giszczak przeciwko Polsce ETPC nie miał wątpliwości, że zarówno odmowa przepustki na pogrzeb członka rodziny, jak i w celu odwiedzin chorego lub umierającego najbliższego stanowi ingerencję w prawo do poszanowania życia rodzinnego. W sprawie Płoski odmowy dotyczyły możliwości uczestnictwa w pogrzebie aż obojga rodziców, którzy zmarli w odstępie jednego miesiąca. Według ETPC wielokrotna recydywa, brak gwarancji powrotu do więzienia (Płoski przeciwko Polsce), a nawet przejawianie aroganckiego zachowania w zakładzie karnym i ciężar gatunkowy popełnionego przestępstwa - podżeganie do zabójstwa (Giszczak przeciwko Polsce) — nie mogą uzasadniać odmowy udzielenia przepustki przez władze krajowe. W obu sprawach nie było to „konieczne w demokratycznym społeczeństwie", ponieważ odmowa nie odpowiadała pilnej potrzebie społecznej i nie była proporcjonalna do usprawiedliwionego celu, w jakim była udzielona. Wystarczającym rozwiązaniem było udzielenie przepustki pod konwojem funkcjonariusza Służby Więziennej. Zob. wyrok Europejskiego Trybunału Praw Człowieka z dnia 12 listopada 2002 roku w sprawie Płoski przeciwko Polsce, skarga nr 26761/95; wyrok Europejskiego Trybunału Praw Człowieka z dnia 29 listopada 2011 roku w sprawie Giszczak przeciwko Polsce, skarga nr 40195/08.

27 Zgodnie z treścią art. 8 ust. 1 „każdy ma prawo do poszanowania swojego życia prywatnego i rodzinnego, swojego mieszkania i swojej korespondencji”. Za: Konwencja o Ochronie Praw Człowieka i Podstawowych Wolności sporządzona w Rzymie dnia 4 listopada 1950 roku, zmieniona następnie Protokołami nr 3, 5 i 8 oraz uzupełniona Protokołem nr 2, Dz.U. z 1993 r. Nr 61, poz. 284 ze zm.

28 G.B. Szczygieł, Przepustki - element izolacji penitencjarnej ułatwiajacy reintegracje spoteczna skazanych, [w:] Węzłowe problemy prawa karnego, kryminologii i polityki kryminalnej. Księga pamiatkowa ofiarowana Profesorowi Andrzejowi Markowi, red. V. Konarska-Wrzosek, J. Lachowski, J. Wójcikiewicz, Warszawa 2010, s. 920. 
możliwości uzyskania lub doskonalenia kwalifikacji zawodowych albo przekwalifikowania wewnątrz KOZZD, pozostając zupełnie pozbawieni takiej możliwości również poza nim.

Przygotowanie do życia na wolności w KOZZD okazuje się fikcją. Niemożliwe pozostaje „zapewnienie rzeczywistej perspektywy powrotu do społeczeństwa”, w którą nie wierzą nawet niektórzy terapeuci z Ośrodka, deklarując w trakcie spotkań pacjentom, że nigdy nie opuszczą placówki ${ }^{29}$. Izolowanych nie zachęca się do podjęcia pracy. Nie przewidziano także jakichkolwiek form łagodzenia warunków izolacji ${ }^{30} \mathrm{~W}$ związku z potrzebą przygotowania umieszczonych do życia poza KOZZD, na przykład za pomocą przepustek. Polskie rozwiązania w praktyce nie spełniają wybranych warunków wymogu dystansu terapeutycznej detencji postpenalnej od wykonywania kary pozbawienia wolności, choć jego spełnienie było deklarowane przez twórców ustawy ${ }^{31}$. Znaczące zwiększenie dostępu do aktywności fizycznych, zapewnienie podstawowych warunków do rozwoju osobistego i zawodowego oraz możliwości podejmowania pracy ${ }^{32}$, a także wprowadzenie przepustek jako elementu procesu readaptacyjnego na poziomie ustawowym mogłoby przyczynić się do faktycznej realizacji celów ustawowych i zmiany filozofii Ośrodka.

\section{Trudna sytuacja biegłych i sędziów}

Sądy pytające i wnioskodawcy w sprawie K 6/14 sformułowali liczne zarzuty dotyczące zgodności procedury prowadzącej do orzeczenia o umieszczeniu w Ośrodku (albo o zastosowaniu nadzoru prewencyjnego) w związku z prawem do sądu. Szczególną uwagę zwracano na pozycję i rolę biegłych, a także sędziów w tej procedurze. Przedmiotem krytyki stała się iluzoryczność podejmowania decyzji o zastosowaniu tych środków przez sądy cywilne, które w ocenie sądów pytających i wnioskodawców pozostały zdane wyłącznie na ustalenia biegłych. Dowodzono,

29 Raport KMPT, op. cit., s. 16.

30 „Wszystkie nowoczesne europejskie systemy leczniczych środków zabezpieczających (np. niemiecki czy holenderski) przewidują stopniowe i łagodne odstępowanie od skrajnej izolacji leczonego do tych form terapii, które zakładają bardziej otwarty model leczenia, mniejszy nadzór i kontrolę, zwiększenie świadomego i dobrowolnego udziału pacjenta w procesie terapii, a także pewnej odpowiedzialności za podejmowane przez niego decyzje”. Więcej J.K. Gierowski, L.K. Paprzycki, Niepoczytalność i psychiatryczne środki zabezpieczajace. Zagadnienia prawnomaterialne, procesowe, psychiatryczne i psychologiczne, Warszawa 2013, s. 440.

31 M. Królikowski, A. Sakowicz, Granice legalności postpenalnej detencji sprawców niebezpiecznych, ,Forum Prawnicze” 2013, nr 5, s. 33.

32 A także, co równie istotne, stworzenie warunków do codziennego funkcjonowania gwarantującego przynamniej namiastkę życia na wolności oraz współdecydowania o codziennych, nawet najprostszych wyborach. Może się to odbywać przez umożliwienie i mobilizowanie pacjentów do samodzielnego gotowania, zajęć warsztatowych czy uprawiania ogródka, jak ma to miejsce w warunkach niemieckich. Więcej Co powinno być zmienione w KOZZD w Gostyninie? Wizytacja Rzecznika Praw Obywatelskich, https:/www.rpo.gov.pl/pl/content/wizytacja\%20-rpo-w-osrodku-w-gostyninie (dostęp: 29.03.2020). 
że aktualny stan wiedzy nauk społecznych i medycznych wyklucza możliwość weryfikacji opinii biegłych przez sąd. Z dezaprobatą spotkała się notarialna rola sądów, sprowadzona do urzędowego potwierdzania ustaleń poczynionych przez biegłych. Krytykowano zaniechania ustawodawcze w zakresie niesprecyzowanych wymogów dotyczących przygotowania kryminologicznego i prawnokarnego specjalistów sporządzających opinie. Zarzuty te nie spotkały się jednak z poparciem ze strony TK. Trybunał, powołując się na stanowisko judykatury, podkreślił między innymi, że konieczne jest „umiejętne rozróżnienie pomiędzy kompetencją biegłego do udzielenia informacji i wiadomości specjalnych, niezbędnych do ustalenia i oceny okoliczności sprawy, a kompetencją sądu, jako wyłącznie uprawnionego do ustalenia faktów i ocen (także hipotetycznych) na podstawie tej opinii oraz innych dowodów"33. Nie zgodził się on z tezą o notarialnej roli sądu, wskazując, że weryfikacja ustaleń biegłych dotyczących stanu zdrowia i ewentualnych przyszłych zachowań osoby, której dotyczy wniosek o uznanie za stwarzającą zagrożenie, należy do zakresu stosowania prawa i kompetencji sądu (nie biegłych). Stwierdził również, że zmierzenie stopnia prawdopodobieństwa popełnienia przez osadzonego (w przyszłości) czynu zabronionego z art. 1 pkt 3 ustawy opiera się na dowodach zebranych przez sąd orzekający i całokształcie okoliczności ustalonych w sprawie, w tym na opiniach biegłych. I choć TK potwierdził, że ustalenia biegłych mają „,kluczowe znaczenie”, to w jego ocenie stanowią tylko „część okoliczności”. Trybunał przypomniał również, że sąd, dokonując oceny konieczności zastosowania środków przewidzianych ustawą z 2013 roku, uwzględnia wyniki postępowania terapeutycznego prowadzonego w trakcie wykonywania kary oraz możliwość efektywnego poddania się przez jednostkę stwarzającą zagrożenie terapii w warunkach wolnościowych (art. 14 ust. 1 ustawy).

Zarysowania wymaga też druga grupa zarzutów, dotycząca operatywności i konstytucyjności pojęć wysokiego i bardzo wysokiego prawdopodobieństwa ${ }^{34}$ z perspektywy zasady prawidłowej legislacji. Pozostają one ściśle związane z pracą sędziów orzekających o umieszczeniu w Ośrodku (a także wypisaniu z niego) oraz biegłych przygotowujących opinie na potrzeby sądów w tych sprawach. Od ustalonego stopnia prawdopodobieństwa zależy uznanie skazanego za osobę stwarzającą zagrożenie i zastosowanie środków przewidzianych przez ustawę z 2013 roku. Taka decyzja sądu może oznaczać pozbawienie wolności na wiele lat, a nawet całe życie. Sądy pytające i wnioskodawcy krytykowali zwłaszcza niedookreśloność pojęć wysokiego i bardzo wysokiego prawdopodobieństwa wynikającą z braku ustawowych kryteriów umożliwiających ich rozróżnienie. Prezydent wprost stwierdził, że przepisy ustawy (art. 14 w związku z art. 11)

33 Por. postanowienie Sądu Najwyższego z dnia 13 czerwca 2013 roku w sprawie IV CSK $126 / 13$

34 Stopnie prawdopodobieństwa dotyczą tu popełnienia czynu zabronionego z użyciem przemocy lub groźbą jej użycia przeciwko życiu, zdrowiu lub wolności seksualnej, zagrożonego karą pozbawienia wolności, której górna granica wynosi co najmniej 10 lat. 
„nakładają na biegłych psychiatrów obowiązek niemożliwy do wypełnienia"35, ponieważ nie da się jednoznacznie ustalić stopnia prawdopodobieństwa popełnienia czynu zabronionego w przyszłości. Ich nieprecyzyjność uniemożliwia jednolitą wykładnię i jednolite stosowanie prawa. W ocenie sądu pytającego - Sądu Okręgowego w Lublinie - naruszały one natomiast prawo do sprawiedliwego rozpatrzenia sprawy zagwarantowane przez Konstytucję RP (art. 45 ust. 1). Samo postępowanie miało nie być sprawiedliwe, ponieważ wiązało się ze „,skomplikowanymi zabiegami interpretacyjnymi". TK uznał jednak, że w ustawie nie było konieczne bardziej precyzyjne określenie przesłanek, które pozwalałyby na odróżnienie prawdopodobieństwa wysokiego od bardzo wysokiego. Trybunał, posiłkując się analizą prawno-porównawczą, stwierdził, że zastosowanie w polskich warunkach tych zwrotów niedookreślonych „nie jest jakimś ekscesem legislacyjnym na tle unormowań obowiązujących w innych państwach Europy Zachodniej" ${ }^{36}$. Z rozumowania TK wynikało, że skoro w innych państwach przesłanka niebezpieczeństwa (zagrożenia/ryzyka), którego źródłem może stać się jednostka, pozostaje sformułowana przy użyciu zwrotów niedookreślonych, to podobne pojęcia mogą znaleźć zastosowanie również w Polsce. Taką argumentację miał wspierać również fakt, że pojęcia te nie są żadnym novum w praktyce polskiego prawa karnego. Trybunał nie zauważył jednak, że $\mathrm{w}$ istocie problem nie dotyczy samego wykorzystania w obrębie przepisu zwrotu niedookreślonego (to jest prawdopodobieństwo), lecz tego, że uchwycenie jego znaczenia jest niemożliwe przez próbę dookreślenia go przez (kolejne nieostre) wyrażenia wysoki i bardzo wysoki, które jednocześnie znacząco różnicują środki prawne możliwe do zastosowania w stosunku do osoby stwarzającej zagrożenie. Należy podkreślić, że we fragmentach ustaw innych państw przytaczanych przez TK na poparcie tezy o obecności zwrotów niedookreślonych również w rozwiązaniach innych krajów — w ramach jednego przepisu nie występuje stopniowanie prawdopodobieństwa, które jest obecne w polskiej ustawie z 2013 roku $^{37}$.

W praktyce zarówno biegli, jak i sędziowie od lat borykają się z licznymi problemami związanymi z przygotowaniem (biegli), a następnie analizą opinii (sędziowie), a także oceną stopnia prawdopodobieństwa popełnienia czynu zabronionego w bliżej nieokreślonej przyszłości (biegli i sędziowie). Okazuje się, że zarzuty i wątpliwości zgłaszane przez wnioskodawców i sądy pytające jeszcze $\mathrm{w}$ trakcie postępowania przed Trybunałem są tożsame z problemami, z którymi na co dzień zmagają się sędziowie cywilni stosujący prawo w sprawach o uznanie osoby za stwarzającą zagrożenie i zastosowanie środka przewidzianego przez

35 Wyrok Trybunału Konstytucyjnego z dnia 23 listopada 2016 roku, sygn. akt K 6/14, s. 6.

36 Ibidem, s. 77.

37 M. Bocheński, Practical aspects of assessment of risk of re-offending by "especially dangerous" offenders in the context of the judgment of the Constitutional Tribunal of 23 November 2016 (K 6/14), „Problems of Forensic Sciences” 108, 2016, s. 635. 
ustawę z 2013 roku. Dotyczy to również bieżących trudności praktyków (psychiatrów, psychologów i seksuologów) przygotowujących opinie nie tylko w trakcie postępowania wykonawczego (te opinie mogą stanowić podstawę do skierowania przez dyrektora zakładu karnego wniosku o uznanie osoby za stwarzającą zagrożenie), lecz także podczas postępowania sądowego zmierzającego do ustalenia, czy jednostka stwarza zagrożenie i wykazuje zaburzenia psychiczne, o których mowa w art. 1 pkt 3 ustawy.

Podstawowym problemem pozostaje brak procedur i narzędzi diagnostycznych, które pozwoliłyby na zobiektywizowane i jednoznaczne określenie stopnia prawdopodobieństwa popełnienia czynu zabronionego z art. 1 pkt 3 ustawy, a zwłaszcza odróżnienie prawdopodobieństwa wysokiego od bardzo wysokiego $^{38}$. Ich niedookreślenie powoduje ryzyko całkowicie nieuzasadnionego ${ }^{39}$ lub zbyt szerokiego ${ }^{40}$ ograniczenia wolności i praw jednostek. Od rozróżnienia tych pojęć zależy intensywność oddziaływania ustawy na sytuację osób stwarzających zagrożenie - wykazanie bardzo wysokiego prawdopodobieńst wa oznacza konieczność umieszczenia w KOZZD (pozbawienie wolności), a w y s okiego prawdopodobieństwa — „tylko” jej ograniczenie poprzez mniej dolegliwy nadzór prewencyjny. Dla zastosowania środków przewidzianych w ustawie z 2013 roku konieczne jest stwierdzenie zaburzeń psychicznych, których charakter lub nasilenie wskazuje, że zachodzi co najmniej wysokie prawdopodobieństwo popełnienia przez rzeczoną osobę czynu zabronionego z użyciem przemocy lub groźbą jej użycia przeciwko życiu, zdrowiu lub wolności seksualnej, zagrożonego karą pozbawienia wolności, której górna granica wynosi co najmniej 10 lat. Eksperci podkreślają, że szacowanie ryzyka to najtrudniejsza część diagnozy ${ }^{41}$, a jednocześnie pierwszy i kluczowy element procesu prowadzącego do ustalenia stopnia prawdopodobieństwa zajścia takiego czynu w przyszłości ${ }^{42}$. Kalkulacja ryzyka zajścia przemocowego zachowania może być dokonywana również przez pracowników służb penitencjarnych w celu uchwycenia niebezpieczeństwa stwarzanego nie tylko przez skazanych, którzy kończą odbywanie kary, lecz także przez

38 J.K. Gierowski, Uwagi psychologa sądowego o możliwościach opiniowania o stopniu zagrożenia u osób objętych ustawa z 22 listopada 2013 r., „Przegląd Więziennictwa Polskiego” 2014, nr 82, s. 15; W. Zalewski, op. cit., s. 384.

39 Uznanie osoby za stwarzającą zagrożenie, mimo że prawdopodobieństwo popełnienia przez nią czynu zabronionego z użyciem przemocy lub groźbą jej użycia nie powinno być uznane za wysokie.

40 Zbagatelizowanie przesłanek, które pozwoliłyby na zastosowanie nadzoru prewencyjnego w miejsce orzeczenia o umieszczeniu w Ośrodku.

${ }^{41}$ O szczegółach dotyczących przygotowania opinii psychologicznych, psychiatrycznych i seksuologicznych zob. Funkcjonowanie ustawy dotyczacej ośrodka w Gostyninie. Seminarium w Biurze RPO, https://www.rpo.gov.pl/pl/content/funkcjonowanie-ustawy-o-osrodku-w-gostyninie-seminarium-rpo (dostęp: 11.02.2020).

42 D.A. Crighton, G.J. Towl, Psychology in Prisons, Malden-Oxford-Melbourne 2008, s. $121-$ 122.

Studenckie Prace Prawnicze, Administratywistyczne i Ekonomiczne 37, 2021

(C) for this edition by CNS 
będących w trakcie jej wykonywania ${ }^{43}$. Psychiatrzy zgadzają się, że nie istnieją metody badawcze, które pozwalają stwierdzić ze stuprocentową pewnością, że dana osoba popełni ponownie czyn zabroniony w przyszłości - potwierdzają to też psycholodzy i seksuolodzy ${ }^{44}$. Stopniowanie prawdopodobieństwa najprawdopodobniej nigdy nie będzie wiązać się z absolutną pewnością, choć jego efektem może stać się głęboka ingerencja w wolności i prawa człowieka. Należy dodać, że w literaturze wyróżniono trzy podstawowe metody szacowania ryzyka recydywy, to znaczy nieustrukturowaną ocenę kliniczną, kierunkową ocenę kliniczną oraz najbardziej świadome i rzetelne podejście anamnestyczne, a w ramach niego ustrukturowaną profesjonalną ocenę ryzyka. W Polsce nie używa się tych najnowocześniejszych narzędzi (brakuje ich tłumaczenia i normalizacji), za to wciąż stosuje się nieustrukturowaną ocenę kliniczną. W takiej sytuacji nie może być też mowy o obiektywizacji kryteriów ocen dokonywanych przez biegłych ${ }^{45}$.

W polskich warunkach nieliczni biegli decydują się na wydanie opinii, które w sposób definitywny wykluczają prawdopodobieństwo popełnienia czynu zabronionego w przyszłości. Co więcej, uzasadnione wydaje się przypuszczenie, że biegli wolą prewencyjnie prognozować niebezpieczeństwo niż stwierdzać jego brak. Istnieje kilka powodów, które wpływają na taką postawę biegłych. Po pierwsze, problemem pozostają wspomniane braki w zakresie dostępnych narzędzi i metod diagnostycznych. Po drugie, wśród biegłych pojawiają się (najprawdopodobniej uzasadnione) obawy o odpowiedzialność za wydane opinie. Odpowiedzialność ta przyjmuje nie tylko wymiar społeczny (ostracyzm społeczności lokalnej, spotęgowany przez media zwiastujące popełnienie czynu zabronionego przez osobę, która nie zostanie uznana za stwarzającą zagrożenie, albo przez wypisanego z Ośrodka), ale i prawno-karny, związany z możliwością pociągnięcia do odpowiedzialności biegłego za umyślne lub nieumyślne przedłożenie fałszywej opinii (zwłaszcza w sytuacji, w której osoba nieuznana za zagrożenie albo wypisana z KOZZD popełni czyn zabroniony) ${ }^{46}$. Nowelizacja kodeksu karnego (dalej: k.k.) z 11 marca 2016 roku $^{47}$ i dodanie do art. 233 k.k. ${ }^{48}$ nowego $\S 4$ a, wprowadzającego pociąganie do odpowiedzialności za nieumyślnie fałszywe opiniowanie, jest potencjalnie niebezpieczna. Taka norma wpływa bezpośrednio na procesy decyzyjne biegłych

43 A.M. Kettles, A concept analysis of forensic risk, ,Journal of Psychiatric and Mental Health Nursing" 11, 2004, nr 4, s. 484-493.

44 Funkcjonowanie ustawy dotyczacej ośrodka...

45 M. Bocheński, Kogo „uleczy” Krajowy Ośrodek Zapobiegania Zachowaniom Dyssocjalnym?, „Ruch Prawniczy, Ekonomiczny i Socjologiczny” 2014, z. 3, s. 152-156, 158 i literatura tam przywołana; J.K. Gierowski, Uwagi psychologa sądowego..., s. 26-41.

46 M. Płatek, Kreowanie groźnych, niebezpiecznych i złych, „Archiwum Kryminologii” 41, 2019, nr 1, s. 141-142.

47 Ustawa z dnia 11 marca 2016 roku o zmianie ustawy — Kodeks postępowania karnego oraz niektórych innych ustaw, Dz.U. poz. 437.

48 Ustawa z dnia 6 czerwca 1997 roku — Kodeks karny, Dz.U. z 2020 r. poz. 1444 ze zm. 
i w dodatku ogranicza znaczenie wiadomości specjalnych, które powinny służyć ustaleniu i ocenie okoliczności sprawy, a więc dotarciu do prawdy ${ }^{49}$. Po trzecie, praktyka wskazuje, że opinie biegłych — wbrew założeniom projektodawcy usta$\mathrm{wy}^{50}$ — nie są oderwane od czynu, za które osoby, w stosunku do których toczy się postępowanie o uznanie za stwarzające zagrożenie, zostały skazane i odbyły całą karę ${ }^{51}$. Nie bez znaczenia pozostaje także penalnopopulistyczna atmosfera, która towarzyszyła procesowi uchwalenia ustawy i pozostaje obecna przez ponad siedem lat jej stosowania ${ }^{52}$. Z badań wynika, że biegli w swoich opiniach potrafią wyliczać szereg aktywności i postaw świadczących o postępach resocjalizacyjnych i terapeutycznych skazanego osiągniętych w trakcie odbywania kary. Doceniają oni jego właściwe zachowanie i przebieg kary, umiejętność unikania konfliktów, niekaralność dyscyplinarną, uzyskane nagrody czy chęć powrotu do społeczeństwa, konstatując jednak, że dana osoba wykazuje co najmniej wysokie prawdopodobieństwo (w pierwszej instancji) lub bardzo wysokie prawdopodobieństwo (jak wskazuje Monika Płatek, najczęściej w drugiej instancji) ${ }^{53}$. Tę obserwację potwierdzają analizy opinii psychologicznych dokonane przez Marię Gordon. Najczęściej wynikało z nich, że „nie można wykluczyć, że zachodzi co najmniej wysokie prawdopodobieństwo" ponownego popełnienia czynu zabronionego oraz że nie jest możliwa kategoryczna ocena charakteru i poziomu tego ryzyka ${ }^{54}$. Taka sytuacja udowadnia konieczność ustalenia bardziej precyzyjnych i klarownych kryteriów oceny stopnia prawdopodobieństwa. Potwierdza również tendencję do prewencyjnego prognozowania minimum wysokiego prawdopodobieństwa $\mathrm{w}$ opiniach, a także obawy ${ }^{55}$, które towarzyszą biegłym przy ich sporządzaniu.

Brak kryteriów pozwalających na ocenę stopnia prawdopodobieństwa to także, a może przede wszystkim, problem sędziów, którzy mają ograniczone możliwości precyzyjnej weryfikacji opinii przygotowanych przez biegłych. Z relacji sędziów cywilnych orzekających w tych sprawach wynika, że nie sprawdzają oni wiedzy specjalistycznej biegłych (choć istnieje ryzyko jej nieaktualności). Ocena opinii opiera się między innymi na zbadaniu ich zgodności z logiką, doświadczeniem życiowym i wiedzą powszechną. Sędziowie ci deklarują również, że w trakcie postępowania (w przeciwieństwie do karnistów) łatwiej oderwać im daną osobę

49 T. Widła, Odpowiedzialność karna za wydanie fałszywej opinii, „Palestra — Pismo Adwokatury Polskiej” 2018, nr 10, s. 18.

${ }^{50}$ M. Królikowski, A. Sakowicz, op. cit., s. 31.

51 Jednak Józef Krzysztof Gierowski stwierdza, że prognozowanie zachowań przestępczych wymaga dokładnej analizy popełnionych dotychczas czynów zabronionych. Więcej J.K. Gierowski, Uwagi psychologa sądowego..., s. 42.

52 M. Płatek, Kreowanie groźnych, niebezpiecznych i złych..., s. 136-137.

53 Ibidem.

54 Funkcjonowanie ustawy dotyczacej ośrodka...

55 Ibidem. 
od czynu, za który odbyła już karę. To organ stosujący prawo podejmuje w formie postanowienia decyzję co do uznania osoby za stwarzającą zagrożenie i w konsekwencji zastosowania nadzoru prewencyjnego lub umieszczeniu w KOZZD, nawet jeśli w opinii biegłych to oni przesądzają o stopniu prawdopodobieństwa popełnienia czynu zabronionego $\mathrm{w}$ przyszłości ${ }^{56}$. Niebezpieczna jest $\mathrm{w}$ tym kontekście rutyna sędziów, którzy w sposób negatywny rozpatrują wiele wniosków kierowanych do nich przez izolowanych w Ośrodku ${ }^{57}$. Dlatego z aprobatą należy odnieść się do opinii sędziów deklarujących, że procedura weryfikacji tego, czy niezbędny jest dalszy pobyt danej osoby w KOZZD, jest niesprawna i wymaga zmian ${ }^{58}$. W świetle przytoczonych argumentów rutyna nie jest obca także biegłym. W ten sposób tworzy się zamknięty krąg wzajemnych oddziaływań, ale i odpowiedzialności. Formalnie decydentem jest sąd. Kieruje się on jednak wnioskiem dyrektora zakładu karnego i opiniami biegłych. Ustalenie znaczenia i poziomu wpływu poszczególnych podmiotów na ukształtowanie sytuacji jednostki, która spełnia przesłanki określone w art. 1 ustawy, jest trudne. Nie zwalnia to sędziów, biegłych i dyrektorów jednostek penitencjarnych ze spojrzenia na sprawę z perspektywy godności osoby, której dotyczy postępowanie o uznanie za stwarzającą zagrożenie. Ważenie wartości i bezwzględna chęć zapewnienia bezpieczeństwa społecznego nie może legitymizować wieloletniego, a nawet dożywotniego naruszania wolności i praw izolowanego w KOZZD już po odbyciu kary pozbawienia wolności.

Do tej pory z KOZZD, w trybie przewidzianym przez art. 47 ust. 1 ustawy, wypisano tylko cztery osoby (stan na 31 sierpnia 2021 roku). Utrzymanie dotychczasowych rozwiązań prawnych nie wstrzyma ani nie ograniczy dynamiki wzrostu liczby osób uznanych za stwarzające zagrożenie. Nie wpłynie też na poprawę sytuacji pacjentów umieszczonych w Ośrodku. Zachowanie szkodliwego status quo nie przyczyni się do (r)ewolucji podejścia dyrektorów zakładów karnych, biegłych i sędziów do osób, które mogą zostać uznane za potencjalnie niebezpieczne. Zmiany wymaga nie tylko ustawa z 2013 roku $^{59}$, lecz także proces jej stosowania. W Polsce do oceny ryzyka recydywy dalej stosuje się nieustrukturowaną ocenę kliniczną ${ }^{60}$. Biegli powinni zostać wyposażeni w nowoczesne narzędzia ${ }^{61}$ służące prawidłowej diagnozie i ocenie stopnia prawdopodobieństwa popełnienia przez badaną jednostkę czynu zabronionego w przyszłości. Ograniczyłoby to ryzyko błędu oraz sprzyjało systematycznej aktualizacji wiedzy biegłych ${ }^{62}$, zwiększając

56 Ibidem.

${ }_{57}$ M. Płatek, Kreowanie groźnych, niebezpiecznych i złych..., s. 156.

58 Funkcjonowanie ustawy dotyczacej ośrodka...

59 W niezbędnym zakresie — również jej akty wykonawcze.

${ }^{60}$ M. Bocheński, Practical aspects of assessment of risk..., s. 637.

61 E. Dawidziuk, op. cit., s. 253.

62 Józef Krzysztof Gierowski, powołując się na badania Danuty Hajdukiewicz i Janusza Heitzmana, wprost deklaruje, że biegli psychiatrzy nie znają nowych kryteriów opiniodawczych, 
znaczenie czynników profesjonalnych przy podejmowaniu decyzji. Wykorzystanie $\mathrm{w}$ procesie opiniowania $\mathrm{w}$ polskich warunkach narzędzi związanych z podejściem anamnestycznym mogłoby się przyczynić do wzrostu jakości i pewności opinii 63 , a także wyeliminowania z nich stwierdzeń typu: „Wnoszę o kastrację fizyczną” czy „Matka Boska roni łzę nad tym czynem”64. Rzetelność opinii jest kluczowa, lecz trudna do osiągnięcia w sytuacji, w której kryteria oceny pozostają mało precyzyjne. Nie dziwi więc, że nawet uznani specjaliści, z powodu braku dostępu do profesjonalnych narzędzi, obawy o możliwość ukarania czy też niezgody na instrumentalne wykorzystanie wiedzy medycznej do rozwiązania problemu prawnego ${ }^{65}$ sygnalizowanej jeszcze w trakcie procedowania nad projektem ustawy, nie chcą wydawać opinii w tych sprawach ${ }^{66}$. Potwierdzałoby to tezę, że ustawa z 2013 roku nałożyła na biegłych obowiązek niemożliwy do wypełnienia. Dostarczenie lepszych, bo pewniejszych narzędzi mogłoby też ułatwić pracę sądów cywilnych. Równie istotne pozostają szkolenia dla sędziów, usprawniające ich współpracę z biegłymi ${ }^{67}$. Takie zmiany to szansa na ograniczenie zachowawczości i rutyny sędziów, tzn. na większą otwartość na stosowanie nadzoru prewencyjnego zamiast umieszczenia w KOZZD, na kolejne postanowienia o wypisaniu z Ośrodka oraz możliwość lepszego zrozumienia opinii biegłych.

\section{Protest głodowy w KOZZD}

W Ośrodku 23 czerwca 2020 roku rozpoczął się protest głodowy 30 pacjentów (na 89 umieszczonych, według stanu z 26 czerwca 2020 roku ${ }^{68}$; kolejną osobę osa-

a w dodatku zdarza im się naruszać zasady sumienności i bezstronności. Za: J.K. Gierowski, Uwagi psychologa sadowego..., s. 30 i literatura tam przywołana.

${ }^{63}$ Z wniosków płynących z seminarium w Biurze Rzecznika Praw Obywatelskich dotyczącego funkcjonowania ustawy z 2013 roku wynika, że opinie psychologiczne są obarczone wadami. Brakuje w nich kompleksowych opisów problemów, które należy poddać terapii, i informacji o próbach zmiany postaw skazanego. Opinie seksuologiczne charakteryzuje natomiast coraz niższa jakość i są one dość ogólne. Zob. więcej Funkcjonowanie ustawy dotyczącej ośrodka...

${ }^{64}$ Ibidem.

65 J.K. Gierowski, Apel w zwiąku z wejściem w życie Ustawy z dnia 23 października 2013 roku o postępowaniu wobec osób z zaburzeniami psychicznymi stwarzającymi zagrożenie życia, zdrowia lub wolności seksualnej innych osób oraz wynikającymi z niej dla opieki psychiatrycznej implikacjami organizacyjnymi, diagnostycznymi, terapeutycznymi i opiniodawczymi, „Psychiatria Polska" 47, 2013, nr 6, s. 970.

${ }^{66}$ Zbigniew Lew-Starowicz wprost stwierdził, że wielu dobrych seksuologów nie chce wydawać opinii w sprawach osób, w stosunku do których jest uruchamiana procedura o uznanie za stwarzające zagrożenie. Por. Funkcjonowanie ustawy dotyczacej ośrodka ...

67 E. Dawidziuk, op. cit., s. 253.

68 Zob. Pacjenci KOZZD protestuja m.in. przeciw złym warunkom bytowym. RPO pisze do MZ, www.rpo.gov.pl/pl/content/rpo-pacjenci-kozzd-protestuja-m.in-przeciw-zlym-warunkom-bytowym (dostęp: 28.06.2020). 
dzono w trakcie strajku $\left.{ }^{69}\right)^{70}$. Stał się on wyrazem niezgody umieszczonych na liczne problemy - przybliżone w obu artykułach autora - które pozostawały nierozwiązane od lat. Bezpośrednią przyczyną buntu okazały się między innymi coraz trudniejsze warunki lokalowe i bytowe w KOZZD ${ }^{71}$. Taka sytuacja wynikła z kilku powodów. Wbrew treści rozporządzenia Ministra Zdrowia z dnia 16 stycznia 2014 roku w sprawie Krajowego Ośrodka Zapobiegania Zachowaniom Dyssocjalnym ${ }^{72}$, Ośrodek pozostaje przeludniony; mimo to do końca 2020 roku systematycznie trafiały do niego kolejne osoby. Poza tym w placówce zostały wdrożone nowe ograniczenia, mające zapobiegać rozprzestrzenianiu się koronawirusa. Zgodnie z nimi, od 5 marca 2020 roku w Ośrodku obowiązuje zakaz odwiedzin (został zniesiony w 2021 roku). Dotyczył on członków rodzin umieszczonych i kurierów, doręczających izolowanym artykuły spożywcze i posiłki spoza KOZZD. Wprowadzono również obligatoryjny pomiar temperatury pacjentów i personelu, a pracownicy zostali zobowiązani do noszenia obuwia i ubrań roboczych. Najbardziej zaskakująca wydaje się jednak decyzja dotycząca wyłączenia wentylatorów na korytarzach ${ }^{73}$. W połączeniu z montażem dodatkowych, zabezpieczających blach na lufcikach okien przyczyniła się ona do wzrostu temperatury (dochodzącej latem do $30^{\circ} \mathrm{C}$ ) $\mathrm{w}$ przeludnionych pokojach $^{74}$. W takich warunkach trudno o uniknięcie konfliktów pacjentów z personelem, a tym bardziej o prowadzenie skutecznych oddziaływań terapeutycznych. Nie ulega wątpliwości, że troska o zdrowie i życie izolowanych (oraz personelu) w związku z zaistniałą sytuacją epidemiczną zasługuje na pochwałę. Nie uchroniła ona jednak przed powstaniem w KOZZD ogniska koronawirusa na przełomie października i listopada 2020 roku oraz śmiercią jednego z pacjentów ${ }^{75}$.

69 M. Płatek, Dlaczego uwięzieni w Gostyninie zorganizowali strajk?, https://strajk.eu/kraj-wolnoscid-teoretycznej-o-porozumieniu-zawartym-po-zakonczeniu-strajku-glodowego-w-osrodku-w-gostyninie/?fbclid=IwAR1rZfA8I1fALD7s1AwulCT1W36sBIOG5msRuuD0pZApRJ HSpooqgCViJ2A (dostęp: 10.07.2020).

70 Za: Pacjenci KOZZD protestują... Warto jednakże zauważyć, że z doniesień medialnych, w zależności od daty ich publikacji, wynikało również, że w proteście brało udział około 40 osób (jak niżej Polityka.pl, OKO.press.pl) czy też konkretnie 33 pacjentów (jak wyżej Strajk.eu). Niektóre redakcje informowały o postulatach 18 osób umieszczonych w Ośrodku (na przykład Protest głodowy pacjentów ośrodka dla ,bestii” w Gostyninie, https:/www.polsatnews.pl/wiadomosc/2020-06-25/ protest-glodowy-pacjentow-osrodka-dla-bestii-w-gostyninie/ (dostęp: 28.06.2020).

71 Pacjenci KOZZD protestuja...

72 Rozporządzenie Ministra Zdrowia z dnia 16 stycznia 2014 roku w sprawie Krajowego Ośrodka Zapobiegania Zachowaniom Dyssocjalnym, Dz.U. poz. 89 ze zm.

73 Takie działanie miało być zgodne z zaleceniami Powiatowej Stacji Sanitarno-Epidemiologicznej w Gostyninie, jednak sanepid nic o nich nie wiedział. Potwierdziła to zresztą dziennikarka portalu OKO.press.pl. Więcej M.K. Nowak, Strajk głodowy w Gostyninie. „Mieli przywracać nas społeczeństwu, a buduja twierdzę", https://oko.press/mieli-przywracac-nas-spoleczenstwu-a-buduja-twierdze/ (dostęp: 4.07.2020).

74 Ibidem.

75 Więcej Koronawirus. MZ odpowiada ws. KOZZD. RPO wnosi do Marszałka Senatu o nowelizacje ustawy, https://www.rpo.gov.pl/pl/content/koronawirus-rpo-kozzd-choruje-22-pacjentow-24-pracownikow-na-kwarantannie (dostęp: 2.12.2020). 
W tym kontekście istotny jest sposób, w który pozbawia się wolności i praw osoby umieszczone w Ośrodku. Kierownik KOZZD nie przewidział żadnych rozwiązań, które kompensowałyby kolejne utrudnienia, zwłaszcza w zakresie kontaktu z najbliższymi. Pacjenci proponowali, że widzenia mogłyby zostać czasowo zastąpione przez rozmowy za pośrednictwem komunikatorów internetowych (na przykład Skype). Dyrektor Ośrodka nie wyraził na to $z g_{0 d y}{ }^{76}$, choć z treści art. 29 ust. 2 ustawy z 2013 roku wynika, że może to uczynić tylko jeżeli taki kontakt może spowodować u pacjenta wzrost zagrożenia niebezpiecznymi zachowaniami albo zakłócić prowadzone postępowanie terapeutyczne. Przesłanki te nie powinny być interpretowane rozszerzająco. Na krytykę zasługuje również brak określenia terminu, na który wprowadzono środki prewencji minimalizujące zagrożenie koronawirusem, a nawet okresu czasu, po upływie którego zostanie rozważona konieczność ich dalszego stosowania. W rozwiązaniu ówczesnych problemów nie pomógł brak bezpośredniego kontaktu izolowanych z kierownikiem placówki ${ }^{77}$. Poza poprawą warunków lokalowych i bytowych, protestujący pacjenci domagali się reformy $\mathrm{w}$ zakresie ich traktowania oraz podejścia personelu. Postulowano między innymi zmianę dyrektora KOZZD i kierownika ochrony, ograniczenie liczby pracowników ochrony, odstąpienie od cenzury prasy, korespondencji i telewizji oraz prewencyjnego używania kajdanek, likwidację kamer w łazienkach i toaletach, a także zwiększenie kontaktu z decydentami w ramach Ośrodka poprzez comiesięczne spotkania ${ }^{78}$.

Strajk głodowy zakończył się porozumieniem zawartym 29 czerwca 2020 roku między kierownictwem a pacjentami KOZZD ${ }^{79}$. Wcześniejsza interwencja Ministerstwa Zdrowia pozwoliła na ponowne włącznie klimatyzatorów znajdujących się w przestrzeniach wspólnych Ośrodka. W wyniku protestu władze Ośrodka zgodziły się na wydłużenie spacerów o 30 minut. Poza tym raz w tygodniu pacjenci będą mogli uczestniczyć w półgodzinnych wieczornych spacerach. Praktyką mają stać się comiesięczne spotkania z kierownikiem KOZZD ${ }^{80}$, zagwarantowane umieszczonym na wszystkich oddziałach. Na szczególną uwagę zasługuje zmiana w formie widzeń izolowanych z bliskimi. Osadzeni po raz pierwszy otrzymali szansę na ich odbywanie bez udziału pracownika ochrony, choć dalej pod kontrolą kamer. Nie są już zakazane bezpośrednie kontakty w trakcie takich spotkań — pocałunek

${ }^{76}$ RPO w sprawie sytuacji w Ośrodku w Gostyninie: pytania i informacje dla Dyrektora KOZZD, www.rpo.gov.pl/pl/content/rpo-w-sprawie-sytuacji-w-KOZZD-Gostynin (dostęp: 30.05.2020).

77 Ibidem.

78 P. Reszka, W ośrodku dla ,, bestii” w Gostyninie trwa protest głodowy, https://www.polityka. pl/tygodnikpolityka/spoleczenstwo/1961510,1,w-osrodku-dla-bestii-w-gostyninie-trwa-protest-glodowy.read (dostęp: 28.06.2020); Pacjenci KOZZD protestują...

79 M. Płatek, Dlaczego uwięzieni w Gostyninie zorganizowali strajk?...

80 Odbywały się one od sierpnia 2020 roku, jednak po jakimś czasie władze KOZZD przestały je organizować. Zob. M.K. Nowak, ,Jednemu się udało, wrócił do więzienia. Mówi: inny świat”. Osadzeni w Gostyninie głoduja, https://oko.press/jednemu-sie-udalo-wrocil-do-wiezienia-mowi-inny-swiat-osadzeni-w-gostyninie-gloduja/ (dostęp: 2.03.2021). 
na powitanie i pożegnanie, trzymanie się za rękę czy przytulanie, co sprzyja poszanowaniu życia prywatnego i rodzinnego pacjentów KOZZD (zgodnie z art. 8 EKPC). Zmniejszy się także częstotliwość stosowania kajdanek podczas wyjazdów z Ośrodka - mimo że nie ma przesłanek, które by uzasadniały takie ograniczenie, do rozpoczęcia protestu była to powszechna praktyka. Nie będą one stosowane w stosunku do umieszczonych, którzy ukończyli 70 lat albo zostali uznani przez kadry i władze KOZZD za osoby, które nie stwarzają już zagrożenia, a więc za gotowe do jego opuszczenia. Pacjentom zagwarantowano możliwość posiadania własnych telewizorów, a także laptopów i telefonów z dostępem do internetu oraz korzystania z nich poza pokojem. Tym, którzy nie mają własnych środków, ma zostać zapewniony dostęp do komputera stacjonarnego z łączem internetowym. Zapowiedziano zniesienie cenzury prasy ${ }^{81}$ i korespondencji oraz przywrócenie dowolności w zakresie korzystania z usług kurierskich ${ }^{82}$. Kontrola przesyłek i listów, odbywająca się jednak pod okiem pacjenta, będzie dotyczyła wyłącznie obecności przedmiotów niebezpiecznych i narkotyków. W przypadku filmów i książek zdecydowano, że nie mogą one dotyczyć zbrodni, zabójstw i treści erotycznych, czego ocena może w praktyce okazać się problematyczna i uznaniowa. Po proteście w pokojach mają pojawić się kodeksy cywilne, czajniki, dodatkowe przedłużacze ${ }^{83}$, a prysznice mają być udostępnione przez całą dobę. W widoku kamer z toalet zostanie natomiast zamazany obraz powyżej łydek. W sferze obietnic pozostała poprawa w zakresie sygnału radiowego i telefonicznego, jakości posiłków zapewnianych w Ośrodku (nowy przetarg po zakończeniu umowy z aktualnym dostawcą) i stworzenie palarni. Bez rozwiązania pozostały jednak niektóre kluczowe problemy, zwłaszcza kwestia panującego przeludnienia i braku wystarczającej przestrzeni do życia w KOZZD, która powoduje kolejne trudności. Według władz ,aktualna sytuacja lokalowa uniemożliwia zmniejszenie liczby pacjentów przebywających w jednej sali" 84 . Nie zapadła również decyzja co do zainstalowania klimatyzacji w pokojach. Kwestie kadrowe, a więc zmiany na stanowiskach kierownika Ośrodka

81 W okresie przed protestem z prasy wycinano na przykład „gołe plecy modelek”. Monika Płatek wskazuje na zwrócone egzemplarze „Tygodnika Powszechnego”, „Polityki”, „Przeglądu”, które miały zostać uznane za niestosowane dla pacjentów. Więcej M.K. Nowak, Strajk głodowy w Gostyninie...; M. Płatek, Dlaczego uwięzieni w Gostyninie zorganizowali strajk?...

82 W związku z zagrożeniem koronawirusem, przesyłki dla pacjentów do 6 września 2020 roku mogły być dostarczane do KOZZD tylko przez Pocztę Polską. Od 7 i 12 września umieszczeni mogą ponownie otrzymywać przesyłki kurierskie również za pośrednictwem innych firm oraz zamawiać posiłki od zewnętrznych dostawców. Więcej W KOZZD Gostynin część restrykcji została złagodzona. Efekt uporczywych starań Rzecznika, https://www.rpo.gov.pl/pl/content/w-kozzd-gostynin -lagodzenie-restrykcji (dostęp: 2.03.2021).

83 Do których mogą zostać podłączone — zakupione przez pacjentów — wentylatory. Wcześniej na salę przypadał tylko jeden przedłużacz, co uniemożliwiało stosowanie wentylatora przy łóżku przez więcej niż jedną osobę. Więcej M.K. Nowak, Strajk głodowy w Gostyninie...

84 M. Płatek, Dlaczego uwięzieni w Gostyninie zorganizowali strajk?... 
i ochrony czy też zmniejszenie liczby personelu ochrony, mimo braków w kadrze specjalistycznej, pozostały poza przedmiotem negocjacji ${ }^{85}$.

Czerwcowy protest w KOZZD w sposób dobitny potwierdził obecność licznych problemów, zarysowanych $\mathrm{w}$ artykule $\mathrm{w}$ odniesieniu do rozważań poczynionych przez Trybunał w sprawie K 6/14. Zryw pacjentów przyczynił się do wprowadzenia pierwszych zmian w warunkach bytowych, ale i filozofii Ośrodka, przejawiającej się w sposobie traktowania osób w nim umieszczonych. Uzasadnione pozostaje pytanie, czy zwiększenie dostępu do spacerów, zniesienie zakazu bezpośredniego kontaktu w ramach widzeń, wprowadzenie ograniczeń w bezustannym stosowaniu kajdanek, zapewnienie możliwości przygotowania herbaty w pokoju czy odbycia rozmowy telefonicznej poza nim wymagało strajku izolowanych w KOZZD. Dlaczego chęć do dialogu i minimalna, choć niewystarczająca, mająca wyłącznie formę deklaracji, reakcja ze strony odpowiednich władz publicznych pojawiła się dopiero $\mathrm{w}$ wyniku rozpoczęcia protestu? ${ }^{86} \mathrm{Z}$ perspektywy czasu zaskakuje drobiazgowość i nietrafność ograniczeń wprowadzonych w Ośrodku, także tych, które od początku 2020 roku uzasadniano sytuacją epidemiczną w kraju. Dotyczy to w szczególności braku zgody na zastąpienie widzeń z członkami rodzin rozmowami przez Skype’a, zakazu korzystania z usług kurierów i dostawców innych niż Poczta Polska czy też decyzji o wyłączeniu klimatyzacji w częściach wspólnych placówki. Takie ograniczenia nie przechodzą testu proporcjonalności. Po pierwsze, powyższych restrykcji nie można uznać za przydatne (adekwatne) do osiągnięcia zamierzonych celów. Kontakty za pośrednictwem Skype’a nie mogły narazić pacjentów na zarażenie koronawirusem, podobnie jak działanie klimatyzacji w wyjątkowo przeludnionej przestrzeni, w której niemożliwe jest zachowanie dystansu społecznego. Po drugie, choć ograniczenie dostępu do kurierów i dostawców można uznać za adekwatne dla ochrony przed COVID-19, to nie jest to niewątpliwie środek najmniej uciążliwy z szerszego katalogu dostępnych moż-

85 M.K. Nowak, W Gostyninie sukces strajkujących. Tylko ministerstwo dalej nie umie rozmawiać — ani liczyć, https://oko.press/w-gostyninie-sukces-strajkujacych/ (dostęp: 5.07.2020); M. Płatek, Dlaczego uwięzieni w Gostyninie zorganizowali strajk?...

86 Biuro prasowe Ministerstwa Zdrowia 29 czerwca 2020 roku poinformowało, że „w porozumieniu z Ministerstwem Sprawiedliwości prowadzone są prace, których celem jest przygotowanie nowelizacji ustawy o postępowaniu wobec osób z zaburzeniami psychicznymi stwarzających zagrożenie życia, zdrowia lub wolności seksualnej innych osób”. Zmiany mają objąć między innymi ustawową regulację praw i obowiązków pacjentów. Ministerstwo deklaruje również chęć budowy nowego docelowego Ośrodka, dlatego w projekcie przewidziano zmiany w zakresie maksymalnych limitów środków finansowych przeznaczonych na placówkę, tak aby zabezpieczyć środki przewidziane na trzyletnią inwestycję. Więcej zob. Protest glodowy w Gostyninie nadal trwa. MZ prowadzi negocjacje, https://www.rynekzdrowia.pl/Polityka-zdrowotna/Protest-glodowy-pacjentow-KOZZD-w-Gostyninie-nadal-trwa-MZ-prowadzi-negocjacje,209516,14.html (dostęp: 6.07.2020); Strajk głodowy w Gostyninie zakończony. Jest porozumienie, https://wiadomosci.dziennik.pl/wydarzenia/ artykuly/7757124,gostynin-osrodek-protest-glodowy-negocjacje-pacjenci.html (dostęp: 6.07.2020). 
liwości, czyli konieczny (niezbędny). W tym przypadku wystarczyłoby przetrzymać przesyłkę i przekazać ją umieszczonemu po upływie określonego czasu, na przykład jednej doby. Niezrozumiałe jest w tym kontekście selekcyjne podejście do takich firm i czasowe dopuszczenie świadczenia usług wyłącznie przez Pocztę Polską. Odcięcie od rodzin i wyłączenie klimatyzacji również należy uznać za najbardziej dolegliwe, a więc niekonieczne, ponieważ istniała możliwość zastosowania łagodniejszych restrykcji (na przykład dostęp do Skype'a w wyznaczonych godzinach). Po trzecie, efekty wspomnianych ograniczeń nie zostały zbilansowane z ciężarami nałożonymi na pacjentów (proporcjonalność sensu stricto). Choć doprowadziły one do naruszenia więzi rodzinnych i pogorszenia warunków bytowych, to nie uchroniły Ośrodka przed powstaniem w nim ogniska koronawirusa, ponieważ rzeczywistym zagrożeniem nie były zachowania pacjentów, lecz przeludnienie KOZZD i jego liczny personel. Trudno nie odnieść wrażenia, że liczne decyzje władz placówki dotyczące funkcjonowania pacjentów w Ośrodku nie miały wyraźnej podstawy prawnej w pełnej luk ustawie, co więcej — okazywały się niepotrzebne, a w dodatku niweczyły już i tak ograniczone możliwości oddziaływań terapeutycznych. Dyrekcji nie sprzyjał brak odpowiedniego wsparcia ze strony przedstawicieli odpowiednich ministerstw. Protest nie okazał się jednak antidotum na wszystkie problemy.

\section{Podsumowanie}

Strajk pacjentów KOZZD, zakończony 29 czerwca 2020 roku, przyczynił się do poprawy warunków bytowych oraz zmian w sposobie traktowania umieszczonych przez kierownictwo i personel Ośrodka. Choć charakter i waga spełnionych żądań mogą wydawać się nam błahe, z perspektywy osób uznanych za niebezpieczne, które co do zasady bezterminowo pozbawia się wolności poprzez umieszczenie w KOZZD, był to ważny i potrzebny krok. Protest izolowanych nie zapoczątkował procesu przemian, które zbliżyłyby codzienne funkcjonowanie polskiego Ośrodka do praktyki holenderskiej ${ }^{87}$ czy też niemieckiej ${ }^{88}$. Na początku lutego $2021 \mathrm{roku}$ miał miejsce kolejny protest głodowy pacjentów. Nowelizacja ustawy z 2013 roku

87 Więcej M.V. Smeekens, P. Braun, Long-Term Forensic Psychiatric Care: The Dutch Perspective, [w:] Long-Term Forensic Psychiatric Care. Clinical, Ethical and Legal Challenges, red. B. Völlm, P. Braun, Cham 2019, s. 235-250; J. de Boer, J. Gerrits, Learning from Holland: the TBS system, „Psychiatry” 6, 2007, nr 11, s. 459-461; M. Drost, Psychiatric assessment after every six years of the TBS order in the Netherlands, „International Journal of Law and Psychiatry” 2006, nr 4, s. 257-261; E. Siedlecka, Coraz więcej osadzonych w Gostyninie. Będzie bunt?, https://www. polityka.pl/tygodnikpolityka/spoleczenstwo/1772004,1,coraz-wiecej-osadzonych-w-gostyninie-bedzie-bunt.read (dostęp: 29.07.2020).

${ }^{88}$ Więcej Ośrodki dla osób stwarzających zagrożenie w Polsce i Niemczech — porównanie, https://www.rpo.gov.pl/pl/content/o\%C5\%9Brodki-dla-os\%C3\%B3b-stwarzaj\%C4\%85cych-zagro\%C5\%BCenie-w-polsce-i-niemczech-\%E2\%80\%93-por\%C3\%B3wnanie (dostęp: 30.07.2020); M.K. Nowak, Ośrodek w Gostyninie gorszy niż więzienie... 
stanowi na razie wyłącznie obietnicę, choć ministerialna deklaracja pojawiła się jeszcze w lutym 2020 roku $^{89}$, a więc przed wybuchem pandemii koronawirusa i rozpoczęciem czerwcowego strajku. Skoro liczne problemy pozostają nierozwiązane od lat, wskazany jest sceptycyzm. Niemniej wymagają one współdziałania kierownictwa KOZZD z właściwymi ministerstwami, Rzecznikiem Praw Obywatelskich, a także organizacjami pozarządowymi, lekarzami i prawnikami, którzy monitorują sytuację Ośrodka.

Sytuacja zagrożenia koronawirusem, która wpłynęła również na rzeczywistość innych placówek leczniczych i penitencjarnych, potwierdziła, że w KOZZD nie istnieją procedury na wypadek tak zwanych sytuacji nadzwyczajnych, jak na przykład trudna sytuacja epidemiczna, potencjalnie niebezpieczna dla pacjentów, ale także ich protest głodowy. Okazało się, że zasadnicza bezterminowość dotyczy nie tylko pobytu w Ośrodku, ale i arbitralnie wprowadzanych ograniczeń, co znajduje odzwierciedlenie w często aneksowanych ,Wewnętrznych regulaminach organizacyjno-porządkowych pobytu pacjenta" wszystkich czterech oddziałów placówki (dopiero w 2021 roku zastąpił je jeden dokument). Powodem takiego stanu rzeczy jest zwłaszcza skąpa regulacja problematyki wolności i praw osób umieszczonych w KOZZD na poziomie ustawowym. Dyskrecjonalna władza kierownictwa Ośrodka wydaje się w wielu sprawach niczym nieograniczona, ponieważ poza przedmiotem regulacji znalazła się szeroka materia dotycząca szczegółów przyjętej metodyki terapeutycznej, warunków bytowych, a także reguł życia w KOZZD — dostępu do aktywności fizycznej, możliwości podejmowania pracy czy uczestnictwa w kształceniu lub doskonaleniu zawodowym (na co wskazywałem w drugim rozdziale tego tekstu i wcześniejszym artykule). Przykład rozwiązań niemieckich potwierdza, że kwestie te można wyczerpująco uregulować w ustawie, z pożytkiem nie tylko dla umieszczonych, ale i dla władz, kadr terapeutycznych i innych pracowników, którym ustawodawca wyznacza przejrzyste i precyzyjne zasady prowadzonych oddziaływań terapeutycznych i codziennej pracy z izolowanymi.

W Polsce przygotowanie pacjentów KOZZD do życia na wolności dalej pozostaje fikcją. Detencja służy wyłącznie detencji, a nie terapii i powrotowi do społeczeństwa. Zmianie sytuacji nie sprzyja dotychczasowa praktyka sądów i biegłych. Od wejścia w życie ustawy, czyli 22 stycznia 2014 roku, do 13 marca 2020 roku dyrektorzy zakładów karnych złożyli do sądów łącznie 275 wniosków o uznanie osób za stwarzające zagrożenie. Sądy wydały 88 postanowień o umieszczeniu w Ośrodku oraz 120 o zastosowaniu nadzoru prewencyjnego ${ }^{90}$. W przeważającej

89 Zespól roboczy MS pracuje nad zmianami ustawy dotyczącej Ośrodka w Gostyninie, www.rpo. gov.pl/pl/content/zespol-roboczy-ms-pracuje-nad-zmianami-ustawy-dot-kozzd (dostęp: 30.07.2020).

90 Za: Stużba Więzienna podaje dane statystyczne ws. KOZZD, https://www.rpo.gov.pl/pl/content/sluzba-wiezienna-podala-rpo-dane-statystyczne-ws-kozzd (dostęp: 30.07.2020). 
części spraw (ponad 75\%) uznano, że jednostka stanowi zagrożenie ${ }^{91}$. Przez ponad siedem lat niewielu osadzonych opuściło KOZZD. Dane te wyraźnie obrazują podejście i atmosferę towarzyszące już od połowy 2012 roku kategorii osób, które mimo odbycia w pełni swoich kar w sposób dotkliwy pozbawia się wolności w Ośrodku. W ocenie Trybunału w sprawie K 6/14 ustawa została uznana za zasadniczo zgodną z Konstytucją RP. To jednak nie powód, aby nie dostrzegać zaniedbań i problemów w jej treści i praktyce stosowania, zwłaszcza w codziennym funkcjonowaniu KOZZD. Nowelizacja ustawy jest ważna i konieczna. W przypadku Ośrodka musi ona jednak pozostać sprzężona ze zmianą filozofii placówki, która przejawia się nie tylko w sprecyzowaniu metod i form terapii czy sposobów zagospodarowania czasu wolnego umieszczonych, lecz także reformie podejścia i postaw personelu do pacjentów oraz stworzeniu rzeczywistych perspektyw opuszczenia KOZZD. Ten ostatni aspekt potwierdzałyby kolejne prawomocne postanowienia sądów o wypisaniu z Ośrodka, na które przyjdzie najprawdopodobniej jeszcze poczekać.

\section{Bibliografia}

Bocheński M., Kogo „uleczy” Krajowy Ośrodek Zapobiegania Zachowaniom Dyssocjalnym?, „Ruch Prawniczy, Ekonomiczny i Socjologiczny” 2014, z. 3, s. 149-161.

Bocheński M., Practical aspects of assessment of risk of re-offending by 'especially dangerous' offenders in the context of the judgment of the Constitutional Tribunal of 23 November 2016 (K 6/14), „Problems of Forensic Sciences” 108, 2016, s. 632-643.

Brzezińska-Rybacka A., Zarys wspótczesnej koncepcji resocjalizacji - metodyka i ogólne zasady, „Roczniki Pedagogiczne” 11 (47), 2019, nr specjalny, s. 109-130.

Crighton D.A., Towl G.J., Psychology in Prisons, Malden-Oxford-Melbourne 2008, DOI: https:// doi.org/10.1002/9781444301724.fmatter.

Dawidziuk E., Izolacja od społeczeństwa po odbyciu w petni kary pozbawienia wolności, „Archiwum Kryminologii” 41, 2019, nr 1, s. 219-260, DOI: https://doi.org/10.7420/AK2019E.

Boer J. de, Gerrits J., Learning from Holland: the TBS system, „Psychiatry” 6, 2007, nr 11, s. 459461, DOI: https://doi.org/10.1016/j.mppsy.2007.08.008.

Drost M., Psychiatric assessment after every six years of the TBS order in the Netherlands, „International Journal of Law and Psychiatry" 29, 2006, nr 4, s. 257-261, DOI: https://doi.org/10.1016/j. ijlp.2005.04.006.

Gierowski J.K., Apel w związu z wejściem w życie Ustawy z dnia 23 października 2013 roku o postępowaniu wobec osób z zaburzeniami psychicznymi stwarzajacymi zagrożenie życia, zdrowia lub wolności seksualnej innych osób oraz wynikającymi z niej dla opieki psychiatrycznej im-

91 Mimo wysokich, wielomilionowych kosztów, które generuje ustawa, co szczegółowo określa jej art. 56. Zastrzeżenia do założeń finansowych zgłaszano jeszcze przed uchwaleniem aktu, podkreślając znaczne niedofinansowanie psychiatrii w Polsce, gdzie — według szacunków — ponad dwa miliony osób pozostają bez wystarczającej opieki. Więcej M. Jarema, Opinia Konsultanta Krajowego $w$ dziedzinie psychiatrii z dnia 24 kwietnia 2013 r. do projektu ustawy o postępowaniu wobec osób zaburzonych psychicznie stwarzajacych zagrożenie dla życia, zdrowia lub wolności seksualnej innych osób, https://legislacja.rcl.gov.pl/docs//2/128528/128531/128534/dokument73682.pdf, s. 5 (dostęp: 30.07.2020). 
plikacjami organizacyjnymi, diagnostycznymi, terapeutycznymi i opiniodawczymi, „Psychiatria Polska" 47, 2013, nr 6, s. 967-972.

Gierowski J.K., Uwagi psychologa sądowego o możliwościach opiniowania o stopniu zagrożenia u osób objętych ustawą z 22 listopada 2013 r., „Przegląd Więziennictwa Polskiego” 2014, nr 82, s. $15-46$.

Gierowski J.K., Paprzycki L.K., Niepoczytalność i psychiatryczne środki zabezpieczajace. Zagadnienia prawnomaterialne, procesowe, psychiatryczne i psychologiczne, Warszawa 2013.

Jaworska A., Aktywność fizyczna w zakładach karnych a podstawowe wymiary osobowości męzczyzn odbywajacych kare pozbawienia wolności, ,Resocjalizacja Polska” 2015, nr 9, s. 137-157.

Kettles A.M., A concept analysis of forensic risk, ,Journal of Psychiatric and Mental Health Nursing” 11, 2004, nr 4, s. 484-493, DOI: https://doi.org/10.1111/j.1365-2850.2004.00752.x.

Konopczyński M., Metody twórczej resocjalizacji. Teoria i praktyka wychowawcza, Warszawa 2010.

Kosendiak A., Trzeciak D., Motywy i czynniki warunkujące poziom aktywności fizycznej aresztowanych oraz skazanych $w$ warunkach izolacji, „Rozprawy Naukowe Akademii Wychowania Fizycznego we Wrocławiu" 2019, nr 64, s. 70-80.

Królikowski M., Sakowicz A., Granice legalności postpenalnej detencji sprawców niebezpiecznych, „Forum Prawnicze” 2013, nr 5, s. 17-34.

Machel H., Rodzina skazanego jako współuczestnik jego resocjalizacji penitencjarnej, readaptacji i reintegracji społecznej, ,Resocjalizacja Polska” 2014, nr 7, s. 45-57.

Płatek M., Kreowanie groźnych, niebezpiecznych i złych, „Archiwum Kryminologii” 41, 2019, nr 1, s. 125-217, DOI: https://doi.org/10.7420/AK2019D.

Płatek M., Niebezpieczni w prawie karnym - Legal fiction czy fiction of legality?, [w:] Ksiega pamiątkowa prof. Lecha Gardockiego. Między nauka a praktyka prawa karnego, red. S. Żółtek, Warszawa 2014, s. 273-293.

Poklek R., Wpływ aktywności fizycznej na poziom agresji młodocianych przestępców, „Zeszyty Naukowe Wyższej Szkoły Pedagogiki i Administracji w Poznaniu” 2006, nr 2, s. 234-243.

Smeekens M.V., Braun P., Long-Term Forensic Psychiatric Care: The Dutch Perspective, [w:] Long-Term Forensic Psychiatric Care. Clinical, Ethical and Legal Challenges, red. B. Völlm, P. Braun, Cham 2019, s. 235-250, DOI: https://doi.org/10.1007/978-3-030-12594-3.

Szczygieł G.B., Przepustki - element izolacji penitencjarnej ułatwiajacy reintegracje społeczna skazanych, [w:] Węzłowe problemy prawa karnego, kryminologii i polityki kryminalnej. Księga pamiatkowa ofiarowana Profesorowi Andrzejowi Markowi, red. V. Konarska-Wrzosek, J. Lachowski, J. Wójcikiewicz, Warszawa 2010, s. 910-925.

Świergała A., Łączność skazanych ze światem zewnętrznym - kontakty poza murami zakładu karnego, „Studenckie Zeszyty Naukowe” 22, 2019, nr 41, s. 153-168.

Widła T., Odpowiedzialność karna za wydanie fatszywej opinii, „Palestra - Pismo Adwokatury Polskiej" 2018, nr 10, s. 13-20.

Zalewski W., Detencja „terapeutyczna” - wątpliwości konstytucyjne i polityczno-kryminalne w kontekście ustawy o „, bestiach”, „Gdańskie Studia Prawnicze” 2018, nr 40, s. 371-388.

\section{Źródła internetowe}

Baczyński M., Schwertner J., Dobra i zła Janinka. Dlaczego państwo zawiodło obie?, https://wiadomosci.onet.pl/tylko-w-onecie/dobra-i-zla-janinka-dlaczego-panstwo-zawiodlo-obie/hl7nc5c.

Co powinno być zmienione w KOZZD w Gostyninie? Wizytacja Rzecznika Praw Obywatelskich, https://www.rpo.gov.pl/pl/content/wizytacja\%20-rpo-w-osrodku-w-gostyninie.

Funkcjonowanie ustawy dotyczacej ośrodka w Gostyninie. Seminarium w Biurze RPO, https://www. rpo.gov.pl/pl/content/funkcjonowanie-ustawy-o-osrodku-w-gostyninie-seminarium-rpo. 
Koronawirus. MZ odpowiada ws. KOZZD. RPO wnosi do Marszałka Senatu o nowelizację ustawy, https://www.rpo.gov.pl/pl/content/koronawirus-rpo-kozzd-choruje-22-pacjentow-24-pracownikow-na-kwarantannie.

Nowak M.K., ,Jednemu się udało, wrócił do więzienia. Mówi: inny świat”. Osadzeni w Gostyninie głoduja, https://oko.press/jednemu-sie-udalo-wrocil-do-wiezienia-mowi-inny-swiat-osadzeni-w-gostyninie-gloduja/.

Nowak M.K., Ośrodek w Gostyninie gorszy niż więzienie. Taki sam w Niemczech leczy i pomaga wrócić do normalnego życia, https://oko.press/niemiecki-osrodek-dla-niebezpiecznych/.

Nowak M.K., Strajk głodowy w Gostyninie. „Mieli przywracać nas społeczeństwu, a buduja twier$d z e ̨$,' https://oko.press/mieli-przywracac-nas-spoleczenstwu-a-buduja-twierdze.

Nowak M.K., W Gostyninie sukces strajkujących. Tylko ministerstwo dalej nie umie rozmawiać ani liczyć, https://oko.press/w-gostyninie-sukces-strajkujacych/.

Ośrodki dla osób stwarzających zagrożenie w Polsce i Niemczech - porównanie, https:// www.rpo.gov.pl/pl/content/o\%C5\%9Brodki-dla-os\%C3\%B3b-stwarzaj\%C4\%85cych-zagro\%C5\%BCenie-w-polsce-i-niemczech-\%E2\%80\%93-por\%C3\%B3wnanie.

Pacjenci KOZZD protestuja m.in. przeciw złym warunkom bytowym. RPO pisze do MZ, www.rpo. gov.pl/pl/content/rpo-pacjenci-kozzd-protestuja-m.in-przeciw-zlym-warunkom-bytowym.

Płatek M., Dlaczego uwięzieni w Gostyninie zorganizowali strajk?, https://strajk.eu/kraj-wolnoscid-teoretycznej-o-porozumieniu-zawartym-po-zakonczeniu-strajku-glodowego-w-osrodku-w-gostyninie/.

Protest głodowy pacjentów ośrodka dla „,bestii” w Gostyninie, https://www.polsatnews.pl/wiadomosc/2020-06-25/protest-glodowy-pacjentow-osrodka-dla-bestii-w-gostyninie.

Protest glodowy w Gostyninie nadal trwa. MZ prowadzi negocjacje, https://www.rynekzdrowia. pl/Polityka-zdrowotna/Protest-glodowy-pacjentow-KOZZD-w-Gostyninie-nadal-trwa-MZ-prowadzi-negocjacje,209516,14.html.

Reszka P., W ośrodku dla ,bestii” w Gostyninie trwa protest głodowy, https://www.polityka.pl/ tygodnikpolityka/spoleczenstwo/1961510,1,w-osrodku-dla-bestii-w-gostyninie-trwa-protest-glodowy.read.

RPO w sprawie sytuacji w Ośrodku w Gostyninie: pytania i informacje dla Dyrektora KOZZD, www.rpo.gov.pl/pl/content/rpo-w-sprawie-sytuacji-w-KOZZD-Gostynin.

Siedlecka E., Coraz więcej osadzonych w Gostyninie. Będzie bunt?, https://www.polityka.pl/tygodnikpolityka/spoleczenstwo/1772004,1,coraz-wiecej-osadzonych-w-gostyninie-bedzie-bunt. read.

Stużba Więzienna podaje dane statystyczne ws. KOZZD, https://www.rpo.gov.pl/pl/content/sluzba-wiezienna-podala-rpo-dane-statystyczne-ws-kozzd.

Strajk głodowy w Gostyninie zakończony. Jest porozumienie, https://wiadomosci.dziennik.pl/wydarzenia/artykuly/7757124,gostynin-osrodek-protest-glodowy-negocjacje-pacjenci.html.

Zespót roboczy MS pracuje nad zmianami ustawy dotyczącej Ośrodka w Gostyninie, www.rpo.gov. $\mathrm{pl} / \mathrm{pl} /$ content/zespol-roboczy-ms-pracuje-nad-zmianami-ustawy-dot-kozzd.

\section{Akty prawne}

Konwencja o Ochronie Praw Człowieka i Podstawowych Wolności sporządzona w Rzymie dnia 4 listopada 1950 roku, zmieniona następnie Protokołami nr 3, 5 i 8 oraz uzupełniona Protokołem nr 2, Dz.U. z 1993 r. Nr 61, poz. 284 ze zm.

Rozporządzenie Ministra Zdrowia z dnia 16 stycznia 2014 roku w sprawie Krajowego Ośrodka Zapobiegania Zachowaniom Dyssocjalnym, Dz.U. poz. 89 ze zm.

Ustawa kraju związkowego Dolna Saksonia z dnia 12 grudnia 2012 roku o pobycie w izolacji osób stanowiących zagrożenie dla społeczeństwa, Nds. SVVollzG, https://www.rpo.gov.pl/sites/de- 
fault/files/Ustawa\%20kraju\%20zwi\%C4\%85zkowego\%20Dolna\%20Saksonia\%20o\%20pobycie\%20w\%20izolacji\%20os\%C3\%B3b\%20stanowi\%C4\%85cych\%20zagro\%C5\%BCenie \%20 dla\%20spo\%C5\%82ecze \%C5\%84stwa.pdf.

Ustawa z dnia 6 czerwca 1997 roku — Kodeks karny, Dz.U. z 2020 r. poz. 1444 ze zm.

Ustawa z dnia 6 czerwca 1997 roku — Kodeks karny wykonawczy, Dz.U. z 2021 r. poz. 53 ze zm.

Ustawa z dnia 22 listopada 2013 roku o postępowaniu wobec osób z zaburzeniami psychicznymi stwarzających zagrożenie życia, zdrowia lub wolności seksualnej innych osób, Dz.U. z 2021 r. poz. 1638.

Ustawa z dnia 11 marca 2016 roku o zmianie ustawy — Kodeks postępowania karnego oraz niektórych innych ustaw, Dz.U. poz. 437.

\section{Orzecznictwo}

Postanowienie Sądu Najwyższego z dnia 13 czerwca 2013 roku w sprawie IV CSK 126/13.

Wyrok Drugiego Senatu Federalnego Trybunału Konstytucyjnego z dnia 5 lutego 2004 roku, 2 BvR 2029/01; BVerfGE 109, 133.

Wyrok Drugiego Senatu Federalnego Trybunału Konstytucyjnego z dnia 4 maja 2011 roku, 2 BvR 2365/09, 2 BvR 740/10, 2 BvR 2333/08, 2 BvR 1152/10, 2 BvR 571/10; BVerfGE 128, 326.

Wyrok Europejskiego Trybunału Praw Człowieka z dnia 12 listopada 2002 roku w sprawie Płoski przeciwko Polsce, skarga nr 26761/95.

Wyrok Europejskiego Trybunału Praw Człowieka z dnia 17 grudnia 2009 roku w sprawie M. przeciwko Niemcom, skarga nr 19359/04.

Wyrok Europejskiego Trybunału Praw Człowieka z dnia 29 listopada 2011 roku w sprawie Giszczak przeciwko Polsce, skarga $\mathrm{nr}$ 40195/08.

Wyrok Trybunału Konstytucyjnego z dnia 23 listopada 2016 roku, sygn. akt K 6/14.

\section{Varia}

Jarema M., Opinia Konsultanta Krajowego $w$ dziedzinie psychiatrii z dnia 24 kwietnia 2013 r. do projektu ustawy o postępowaniu wobec osób zaburzonych psychicznie stwarzajacych zagrożenie dla życia, zdrowia lub wolności seksualnej innych osób, https://legislacja.rcl.gov.pl/ docs//2/128528/128531/128534/dokument73682.pdf.

Raport dla rządu Rzeczpospolitej Polskiej z wizyty Europejskiego Komitetu do spraw Zapobiegania Torturom oraz Nieludzkiemu lub Poniżającemu Traktowaniu albo Karaniu (CPT) przeprowadzonej w Polsce w dniach 11-22 maja 2017 roku, CPT (2017) 62, https://www.rpo. gov.pl/pl/content/raport-dla-polski-o-metodach-zapobiegania-torturom-po-polsku-resort-sprawiedliwo\%C5\%9Bci-opublikowa\%C5\%82.

Raport przedstawicieli Krajowego Mechanizmu Prewencji Tortur z wizytacji Krajowego Ośrodka Zapobiegania Zachowaniom Dyssocjalnym w Gostyninie przeprowadzonej w dniach 18-20 lutego 2019 roku (wyciąg), KMP.574.1.2019.JZ, https:/www.rpo.gov.pl/pl/content/kmp/od-1550480400-do-1550653200-wizytacja-w-krajowym-o\%C5\%9Brodku-zapobiegania-zachowaniom-dyssocjalnym-w-gostyninie.

Regulaminy Ośrodka, Biuletyn Informacji Publicznej Krajowego Ośrodka Zapobiegania Zachowaniom Dyssocjalnym w Gostyninie, http://kozzd-gostynin.bip.eur.pl/public/?id=179972. 
